
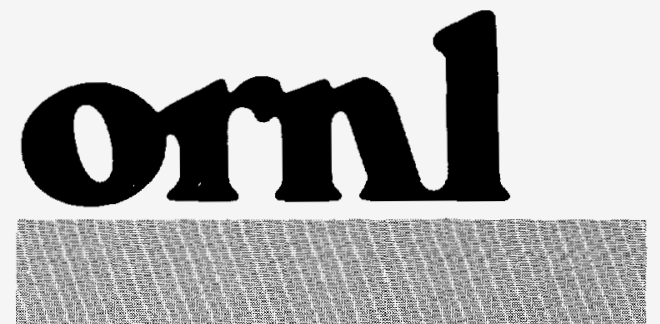

OAK RIDGE NATIONAL LABORATORY

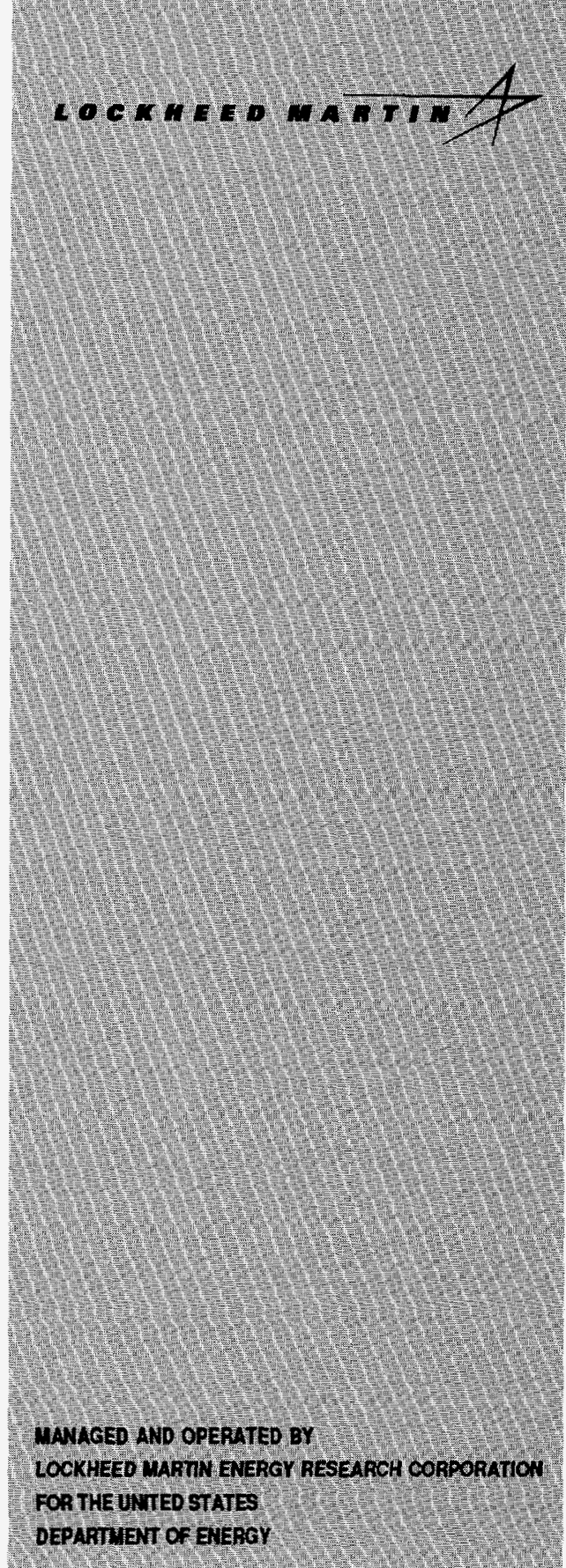

RECFIVED

\author{
APR 301996 \\ OSTI
}

\section{Ancillary-Service Costs for 12 U.S. Electric Utilities}

Brendan Kirby

Eric Hirst 
This report has been reproduced directly from the best available copy.

Available to DOE and DOE contractors from the Otfice of Scientific and Technical Information, P.O. Box 62, Oak Ridge, TN 37831; prices available from (423) 576-8401, FTS 626-8401.

Available to the public from the National Technical Information Service, U.S. Department of Commerce, 5285 Port Royal Rd., Springfield, VA 22161.

This report was prepared as an account of work sponsored by an agency of the United States Government. Neither the United States Government nor any agency thereof, nor any of their employees, makes any warranty, express or implied, or assumes any legal liability or responsibility for the accuracy, completeness, or usefulness of any information, apparatus, product, or process disclosed, or represents that its use would not infringe privately owned rights. Reference herein to any specific commercial product, process, or service by trade name, trademark, manufacturer, or otherwise, does not necessarily constitute or imply its endorsement, recommendation, of favoring by the United States Government or any agency thereof. The views and opinions of authors expressed herein do not necessarily state or reflect those of the United States Government or any agency thereof. 


\section{ANCILLARY-SERVICE COSTS FOR 12 U.S. ELECTRIC UTILITIES}

BRENDAN KIRBY and ERIC HIRST

March 1996

Sponsored by

Competitive Resource Strategies Program

Office of Energy Efficiency and Renewable Energy U.S. Department of Energy

OAK RIDGE NATIONAL LABORATORY

Oak Ridge, Tennessee 37831 managed by

LOCKHEED MARTIN ENERGY RESEARCH CORPORATION for the

U.S. DEPARTMENT OF ENERGY under contract No. DE-AC05-96OR22464 


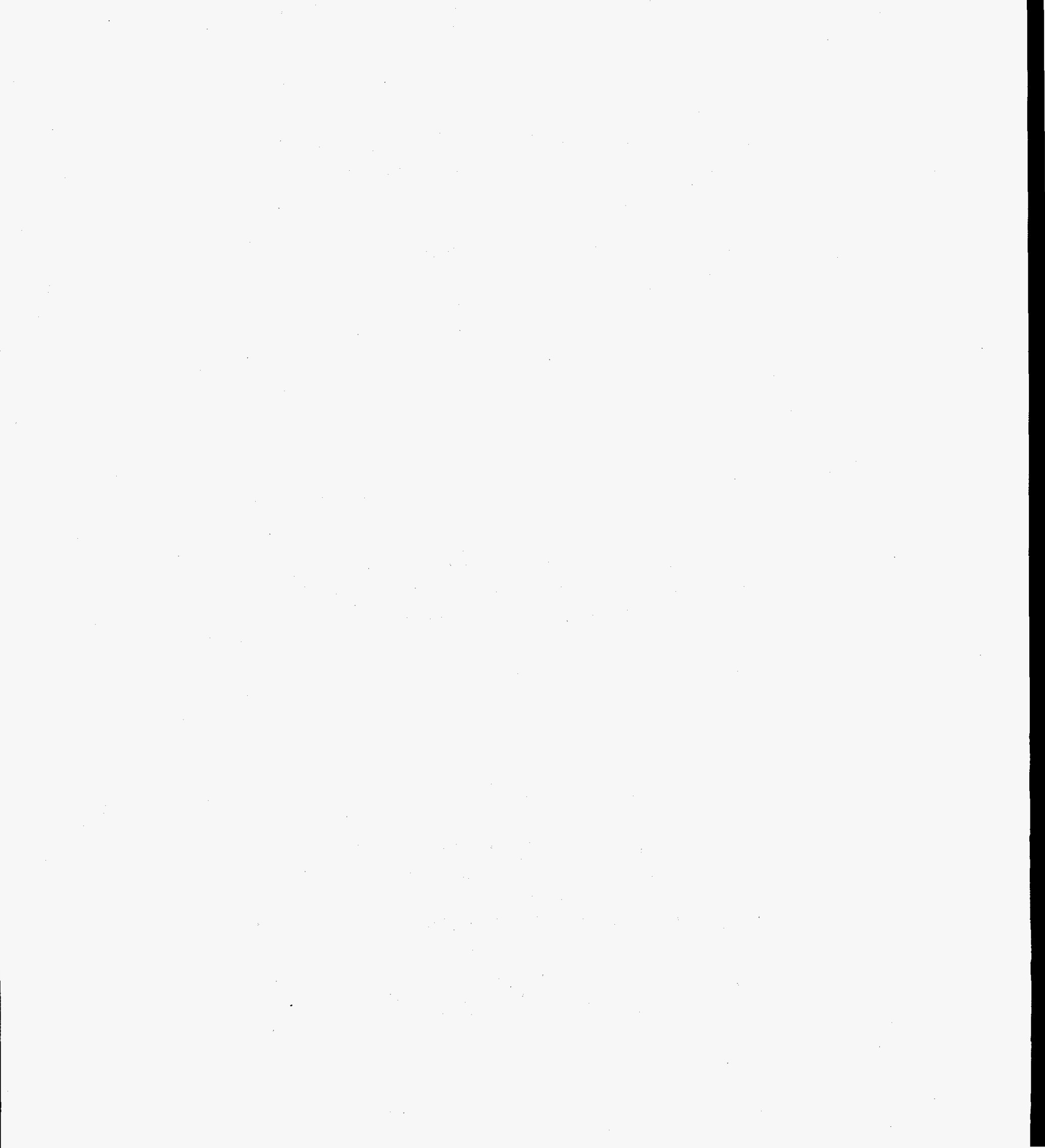




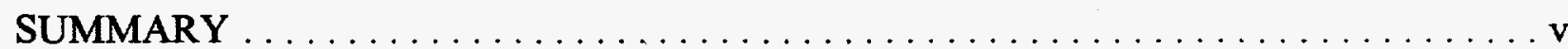

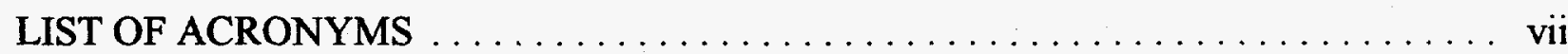

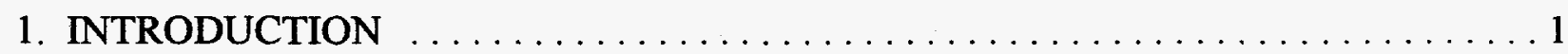

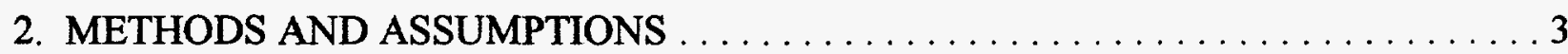

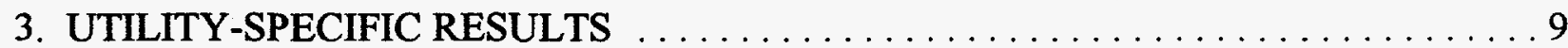

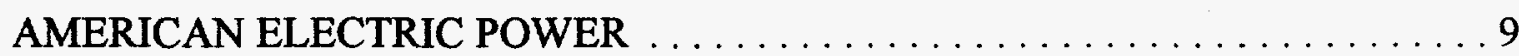

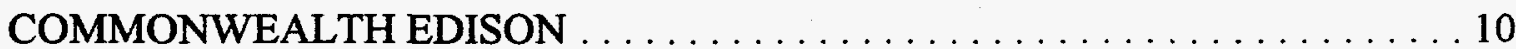

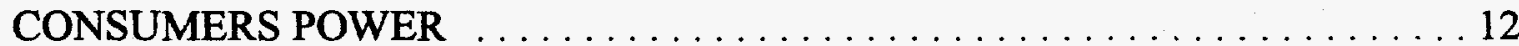

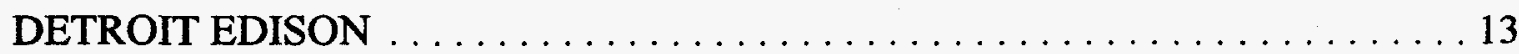

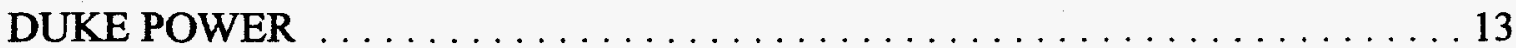

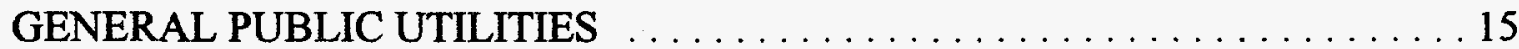

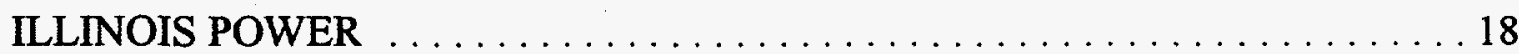

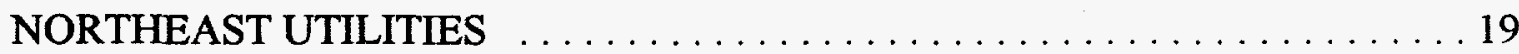

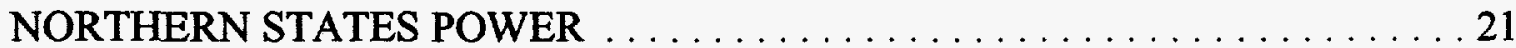

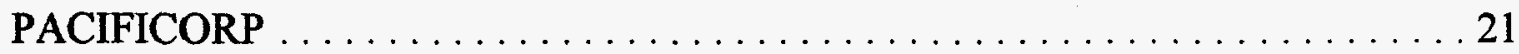

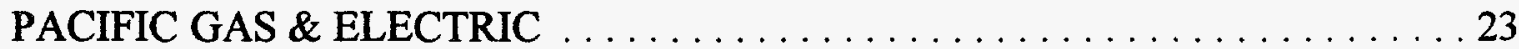

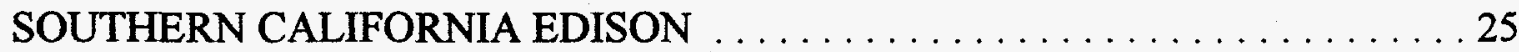

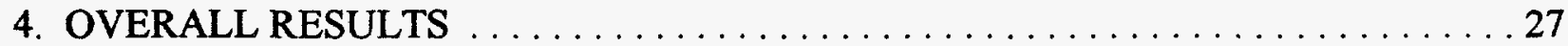

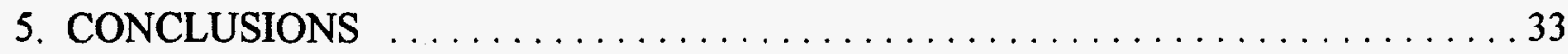

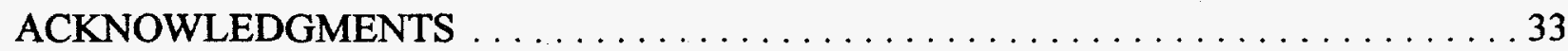

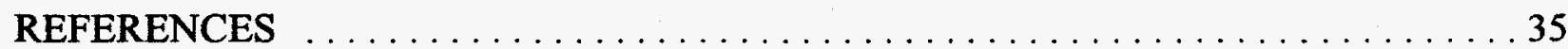



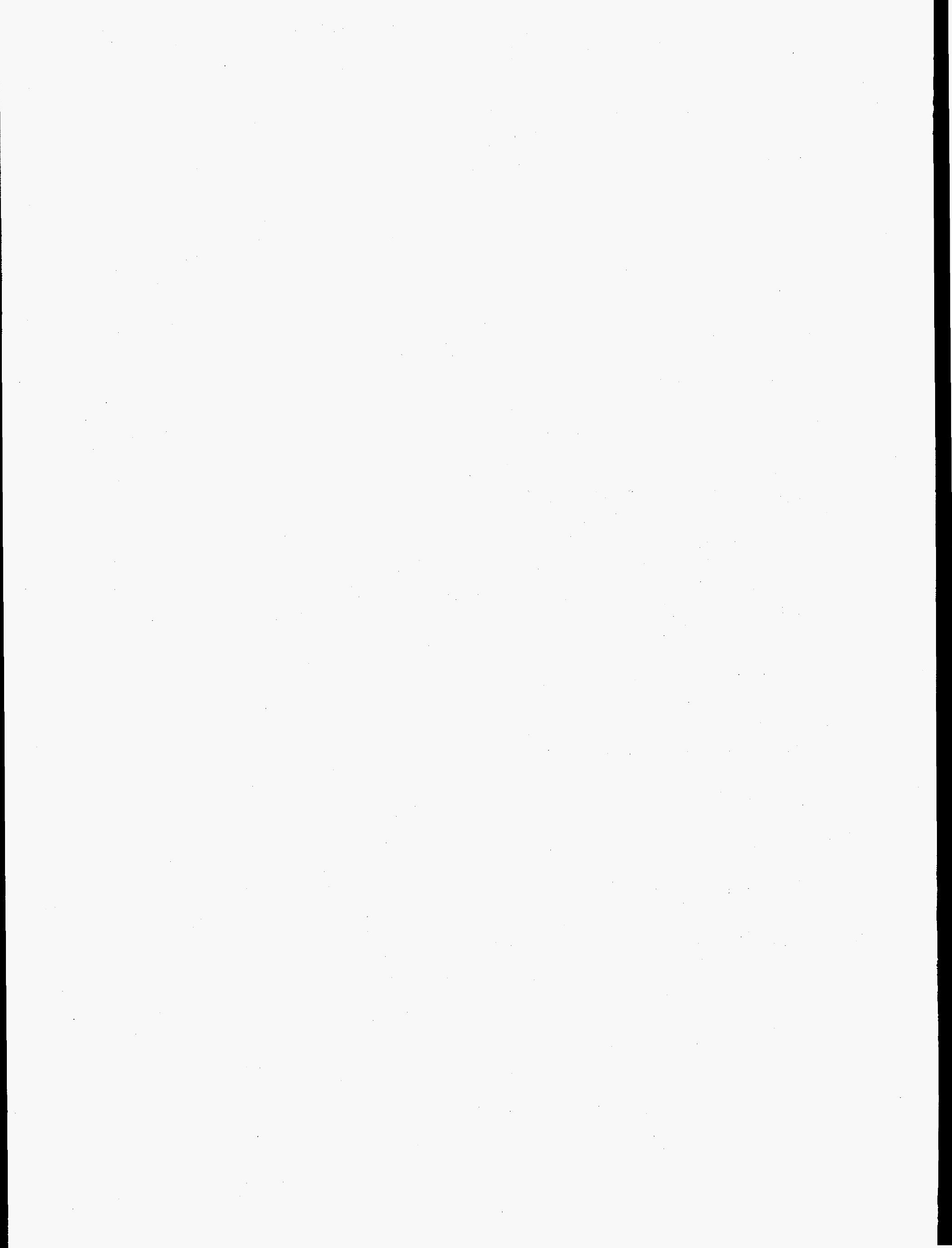


\section{SUMMARY}

Since the Federal Energy Regulatory Commission issued its proposed rule on openaccess transmission in March 1995, ancillary services have been an important and controversial topic within the electricity industry. These services, many of which are required to maintain system reliability, support the basic services of providing and delivering electric energy and power to customers.

Using data, assumptions, and analyses from 12 utilities throughout the United States, we developed estimates of the costs of ancillary services, both in aggregate and by service. These utilities, although a small and nonrepresentative sample of the industry, account for $28 \%$ of U.S. electric-energy production. To facilitate comparison between services and among utilities, we normalized all costs on a $\notin / \mathrm{kWh}$ basis even though many services would not be priced this way.

In aggregate, ancillary-service costs range from 0.15 to $0.68 \notin / \mathrm{kWh}$, with an average of $0.41 \% / \mathrm{kWh}$ for the 12 utilities in our sample. Ancillary services account for 5 to $25 \%$ of total generation and transmission costs, with an average of $10 \%$ (Fig. S-1). Based on total U.S. generation of 2900 thousand GWh in 1994, ancillary services cost almost $\$ 12$ billion per year.

The substantial range in ancillary-service costs and the lack of correlation between these costs and the underlying costs of generation and transmission suggest that additional work is needed to sharpen the definitions of each ancillary service, to identify how much of each service is required, and to establish the fixed and variable costs for each service.

Not surprisingly, the costs for the various services differ substantially (Table S-1). Scheduling and dispatch is very inexpensive, typically costing about $0.018 \notin / \mathrm{kWh}$ and accounting for only $4 \%$ of total ancillary-service costs.

Operating reserves account for the bulk of ancillary-service costs. Load following averages $0.04 \notin / \mathrm{kWh}, 9 \%$ of total cost. Reliability reserve averages $0.07 \notin / \mathrm{kWh}, 16 \%$ of total cost. Supplemental-operating reserve averages $0.07 \mathrm{k} / \mathrm{kWh}, 18 \%$ of total cost. Altogether, these three generation services cost $0.18 \notin / \mathrm{kWh}, 43 \%$ of the total. If transmission constraints are present, the costs for operating reserves and perhaps for other ancillary services could be much higher.

Energy imbalance, assuming that $1 \%$ of customer loads are subject to this penalty, costs $0.05 \notin / \mathrm{kWh}, 11 \%$ of the total. Real-power losses cost $0.12 \notin / \mathrm{kWh}, 30 \%$ of the total. Finally, voltage control costs $0.05 \mathrm{k} / \mathrm{kWh}, 12 \%$ of the total. 
ANCILLARY-SERVICE COSTS $(\$ / \mathrm{kWh})$

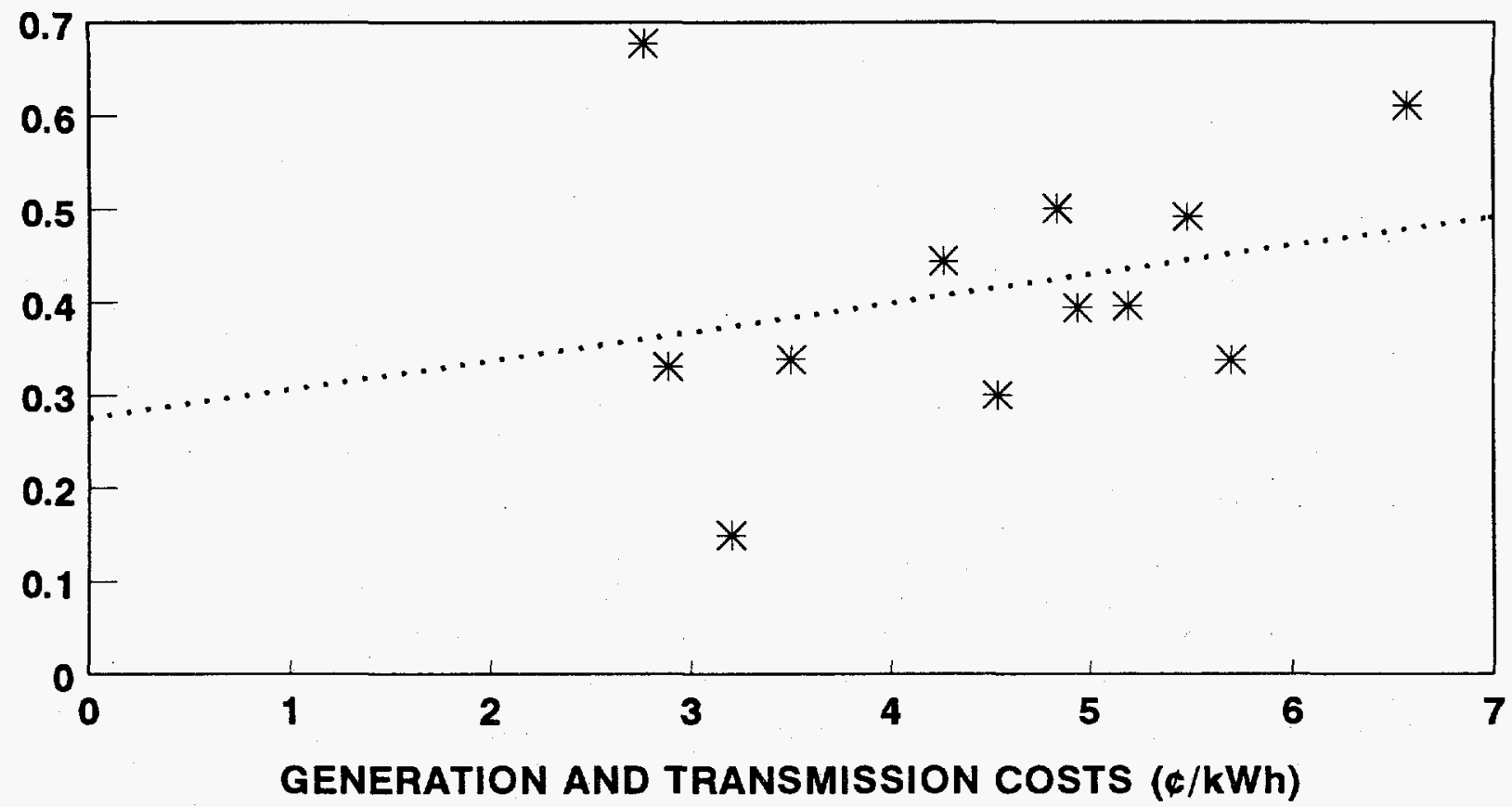

Fig. S-1. Ancillary-service costs as a function of generation and transmission costs for 12 U.S. investor-owned electric utilities.

Table S-1. Ancillary-service costs for 12 U.S. investor-owned utilities

\begin{tabular}{lccc}
\hline & Average & \multicolumn{2}{c}{ As a percentage of } \\
\cline { 3 - 4 }$(\phi / \mathrm{kWh})$ & $\begin{array}{c}\text { Ancillary- } \\
\text { service cost }\end{array}$ & $\begin{array}{c}\text { Generation and } \\
\text { transmission cost }\end{array}$ \\
\hline Scheduling \& dispatch & 0.018 & 4.3 & 0.4 \\
Generation reserves & & & \\
Load following & 0.038 & 9.1 & 0.9 \\
Reliability & 0.066 & 16.0 & 1.5 \\
$\quad$ Supplemental operating & 0.073 & 17.6 & 1.6 \\
Energy imbalance & 0.047 & 11.3 & 1.1 \\
Real-power losses & 0.122 & 29.5 & 2.9 \\
Voltage control & 0.051 & 12.3 & 1.2 \\
Total cost or percent & 0.414 & 100.0 & 9.8 \\
\hline
\end{tabular}




\section{LIST OF ACRONYMS}

$\begin{array}{ll}\text { AEP } & \text { American Electric Power Company } \\ \text { AS } & \text { Ancillary service } \\ \text { COmEd } & \text { Commonwealth Edison Company } \\ \text { FERC } & \text { Consumers Power Company } \\ \text { GPU } & \text { General Public Utilities Corporation } \\ \text { G\&T } & \text { Generation and transmission } \\ \text { IP } & \text { Illinois Power Company } \\ \text { NU } & \text { Northeast Utilities } \\ \text { NSP } & \text { Northern States Power Company } \\ \text { PG\&E } & \text { Pacific Gas \& Electric Company } \\ \text { SCE } & \text { Southern California Edison Company } \\ \text { VAR } & \text { Volt-ampere-reactive }\end{array}$




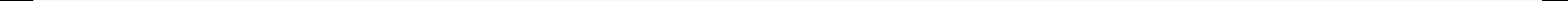




\section{INTRODUCTION}

Ancillary services are those functions performed by electrical generating, transmission, system-control, and distribution-system equipment and people to support the basic services of generating capacity, energy supply, and power delivery (Hirst and Kirby 1996). The Federal Energy Regulatory Commission (FERC 1995) defined ancillary services as "those services necessary to support the transmission of electric power from seller to purchaser given the obligations of control areas and transmitting utilities within those control areas to maintain reliable operations of the interconnected transmission system." FERC divided these services into three categories: "actions taken to effect the transaction (such as scheduling and dispatching services) ... services that are necessary to maintain the integrity [reliability] of the transmission system (such as load following, reactive power support, and system protection services) ... [and] services needed to correct for the effects associated with undertaking a transaction (such as loss compensation and energy imbalance services)."

In March 1995, FERC published a proposed rule to ensure open and comparable access to transmission networks throughout the country. The rule defined six ancillary services and developed pro forma tariffs for these services: scheduling and dispatch, load following, system protection, energy imbalance, loss compensation, and reactive power/voltage control.

- Scheduling and dispatch are the control-area operator functions that schedule generating units and transactions before the fact and control these units in real time to maintain reliability.

- Load following is the use of online generating equipment that is equipped with governors and automatic generation control to track the moment-to-moment fluctuations and the hourly trends in customer loads. In so doing, load following (along with reliability reserve) helps to maintain interconnnection frequency and generation/load balance within the control area.

- System-protection reserves include (1) reliability reserve, the use of spinning and faststart generating equipment that can be fully available within 10 minutes to correct for generation/load imbalances caused by generation and transmission (G\&T) outages; plus (2) supplemental-operating reserve, the use of generating equipment and interruptible load that can be fully available within 30 minutes to back up the 10-minute reserve.

- Energy imbalance is the use of generating equipment and fuel to match any differences between actual and scheduled transactions between suppliers and their customers. 
- Real-power-loss replacement is the use of generating equipment and fuel to compensate for the transmission-system losses associated with power flows from generators to customers.

- Voltage control is the use of generating and transmission-system equipment to inject or absorb reactive power to maintain voltages on the transmission system within required ranges.

See Hirst and Kirby (1996) for additional discussion of these services.

This report provides initial estimates of these costs, based on data from 12 U.S. investorowned utilities. These utilities include American Electric Power (AEP), Consumers Power (CPCo), Commonwealth Edison (ComEd), Detroit Edison, Duke Power, General Public Utilities (GPU), Illinois Power (IP), Northeast Utilities (NU), Northern States Power (NSP), PacifiCorp, Pacific Gas \& Electric (PG\&E), and Southern California Edison (SCE). These utilities operate in seven of the nine regional reliability councils.

We did not obtain cost estimates from consumer-owned utilities (municipalities, cooperatives, or federal utilities). Because these utilities are not required to file open-access tariffs with FERC and because many of these utilities are not vertically integrated, few of them have published estimates of these costs.

Chapter 2 explains the information we obtained from these utilities and the assumptions we made in developing estimates of the costs of ancillary services. Chapter 3 presents results for each of these 12 utilities, and Chapter 4 presents aggregate results. Chapter 5 summarizes these results and suggests additional work. 


\section{METHODS AND ASSUMPTIONS}

We contacted utilities throughout the country and asked for copies of recent transmission filings, work papers, and other materials that could be used to estimate, in aggregate and for each service, the costs of ancillary services. Because most of the material we received was produced in 1995, the services often resemble the six that FERC defined in its proposed rule. The utilities generally used traditional cost-of-service, embedded-cost methods to estimate costs for each service. In some cases, the utility results reflect settlements among various parties to state or FERC proceedings. Nevertheless, these estimates provide a useful starting point from which to estimate market prices for those services that can be competitively provided.

Several utilities were reluctant to provide data and estimates for this project. They were concerned that the rapid changes in FERC and state regulation, as well as in industry operations, would quickly render the numbers they gave us obsolete. ${ }^{*}$ Some utilities, in part to avoid delays in FERC approval of their transmission tariffs, accepted the FERC default of $0.1 \% / \mathrm{kWh}$ for the combination of load following, operating reserves, and voltage control. We decided not to use their tariffs for this project because these three services account for more than half the total cost of ancillary services.

The 12 utilities that provided data sell electricity in 24 states and represent 28 and $23 \%$, respectively, of U.S. electricity generation and retail revenues (Table 1). Thus, although these utilities are not a representative sample of U.S. utilities, they do account for a substantial minority of the electricity industry.

We present results on ancillary-service costs normalized by each utility's requirements sales (sales to retail customers plus firm sales to wholesale customers) in $\not / \mathrm{kWh}$ and as a percentage of G\&T costs. To normalize utility estimates of ancillary-service costs, we first created estimates of each utility's G\&T cost and load factor. We used the data that utilities report to the Energy Information Administration (1995) on FERC Form 1 (FERC 1992) for 1993, obtained from the PowerDat database maintained by Resource Data International, Boulder, Colorado. We summed all the costs associated with G\&T and divided this total dollar amount into the utility's total sources of energy (the sum of generation, purchases, net interchange, and wheeling). These G\&T costs ranged from 2.8 to $6.6 \not / \mathrm{kWh}$ across the 12 utilities. These costs are measured at the generator busbar. In principle, they should be inflated

*For example, the information that Illinois Power provided (summarized in Table 9) showed a 3\% loss factor. A subsequent agreement modified the assumed losses to $2.7 \%$ for demand and $2.05 \%$ for energy. 
by transmission losses (roughly $3 \%$ ) to reflect the prices that wholesale customers would face. In a similar fashion, the ancillary-service costs shown in Tables 3 to 14 should be increased by this percentage. We did not inflate the costs because we lacked data on transmission and distribution losses for each utility.

Table 1. Key features of utilities that provided data on the costs of ancillary services

\begin{tabular}{llcc}
\hline Utility & \multicolumn{1}{c}{ State(s) } & $\begin{array}{c}\text { Total energy } \\
\text { generated and } \\
\text { received, 1993 } \\
\text { (thousand GWh) }\end{array}$ & $\begin{array}{c}\text { Total retail } \\
\text { electric } \\
\text { revenue, 1993 } \\
\text { (billion \$) }\end{array}$ \\
\hline $\begin{array}{llc}\text { American Electric } \\
\text { Power }\end{array}$ & IN, KY, MI, OH, TN, & 157.4 & 4.52 \\
Commonwealth Edison & IL & & \\
Consumers Power & MI & 94.9 & 6.24 \\
Detroit Edison & MI & 35.5 & 1.97 \\
Duke Power & NC, SC & 49.4 & 3.36 \\
General Public Utilities & NJ, PA & 80.7 & 3.68 \\
Illinois Power & IL & 49.4 & 3.43 \\
Northeast Utilities & CT, MA, NH & 23.3 & 1.12 \\
Northern States Power & MN, WI & 49.7 & 3.14 \\
PacifiCorp & CA, ID, MT, OR, UT, & 47.6 & 1.79 \\
& WA, WY & 62.0 & 1.97 \\
Pacific Gas \& Electric & CA & 81.9 & 7.54 \\
Southern California & CA & 81.3 & 7.08 \\
Edison & & & \\
Totals & 24 & 813.1 & 45.8 \\
As \% of U.S. & & 28.2 & 23.1 \\
As\% of U.S. investor-owned utilities & 37.2 & 29.2 \\
\hline
\end{tabular}

Source: Energy Information Administration (1995).

We defined system load factor on the basis of the utility's peak demand and its retailplus-firm-wholesale sales. We used this estimate of load factor to convert certain ancillaryservice prices from $\$ / \mathrm{kW}$-month to $\phi / \mathrm{kWh}$. The utilities, in defining their ancillary-service tariffs, may have used load factors that differed from that of their total system load. For example, Detroit Edison assumed an $82 \%$ load factor for the large industrial customers it thought would seek retail-wheeling services. Using different load factors would affect the revenues collected for ancillary services, especially when the costs are normalized by $\notin / \mathrm{kWh}$. 
As noted above, the data we used to define load factor and wholesale cost are for 1993. However, the utility estimates of ancillary-service costs are generally for 1995, although they are sometimes based on data from earlier years. We ignored these temporal differences. Inflation, which was quite low between 1993 and 1995, would lead us to increase the 1993 dollar amounts. On the other hand, improvements in utility productivity and reductions in fuel costs, reflected in stable or declining electricity prices, would lead us to lower these 1993 dollar amounts. Given the much greater uncertainty in the ancillary-service-cost estimates themselves, we made no adjustments to the 1993 data.

In calculating the cost of transmission-system voltage control, we did not include the cost of customer (local) power-factor correction. We excluded this cost because it is a customer service, not one related to the transmission system.

Not all utilities estimated costs for all the ancillary services. In those cases where the cost for a service was missing, we imputed a value based on the estimates developed by the other utilities in our sample. In other cases, the utility did not disaggregate costs across services. In particular, we were unable to determine unambiguous allocations of operating-reserve costs and amounts among load following, reliability reserve, and supplemental-operating reserve for several utilities. We assumed a reasonable split among the services in those cases.

We had to make assumptions about the amount of some services that customers would use. This is especially true for energy imbalance, for which we assumed that $1 \%$ of total consumption would fall outside the return-in-kind deadband and would therefore be subject to payment to the utility. We assumed that customers would over- and under-generate to the same extent (i.e., $0.5 \%$ of total load in both directions). And we assumed that the customer's own cost for over- or under-generation would be equal to the utility's marginal cost of production (system lambda). Thus, the charge for energy imbalance is

$$
\mathrm{EI}=0.005(\text { penalty }-\lambda)+0.005(\lambda-\text { payment }),
$$

equivalent to

$$
\mathrm{EI}=0.005 \text { (penalty - payment), }
$$

where penalty is the charge in $\not / \mathrm{kWh}$ the utility would impose on a customer that undergenerated, payment is what the utility would pay to the customer if the customer overgenerated, and 0.005 reflects our assumption that customers would over- and under-generate $0.5 \%$ of their annual consumption.

"Utilities have historically required customers to meet minimum power-factor requirements (e.g., $95 \%$ ) and have rates in place for this service. The charges for this service ranged from $\$ 0.18$ to $\$ 0.33 / \mathrm{kVAR}$ month among three utilities in our sample. 
These 12 utilities developed prices differently for various services. For example, the results in Chapter 3 show three forms for pricing generation reserves: (1) capacity charge only, (2) capacity and energy charges based on total consumption, or (3) capacity charge plus an energy charge that is imposed only when the customer uses the reserve. For the two utilities that used this third option (ComEd and NU), we assumed a forced-outage rate of $10 \%$ and, as with energy imbalance, charged only for the increment above system lambda.

Although the details varied substantially from utility to utility and from service to service, the utilities generally used similar methods to calculate the costs and prices for these services. Table 2 shows schematically how a utility might calculate the cost for load following. Of course, the actual calculations are much more complicated than suggested by Table 2 because they include the effects of depreciation, current and deferred income taxes, property taxes, payroll taxes, working capital, administrative and general expenses, and other factors. In addition, the utilities have to make judgments concerning the allocation of costs for certain equipment (e.g., generators) that provides multiple services (e.g., capacity, energy, load following, reliability reserve, supplemental-operating reserve, and voltage control). 
Table 2. Example of an embedded-cost method used to calculate ancillary-service costs: load following

1. Determine the amount of generating capacity (MW) required to provide this service and whether the required amount varies with time (by hour, day of the week, or season).

2. Identify the generating-station capital equipment (generating units, governors, automatic generation control equipment, computers, and so on) that provide this loadfollowing service. Determine how much capacity (up and down) each unit provides.

3. Calculate the annualized capital cost (million \$) for the equipment identified in step 2. (These numbers are based on the fraction of each piece of equipment assigned to load following and on the depreciated values of each piece of equipment multiplied by appropriate fixed-charges rates.)

4. Determine the fixed operations, maintenance, and labor costs for the equipment identified in step 2.

5. Calculate the incremental operating costs (fuel associated with heat-rate degradation from constant cycling, the costs of out-of-merit-order dispatch, plus additional maintenance to compensate for the wear and tear on the units caused by cycling) for the generating units identified in step 2 because of the unit's operation to provide load following. Determine the incremental operating costs, if any, of other equipment used to provide this service.

6. Compute the annualized control-center costs for load following (automatic generation control, computers, and other equipment) plus annual labor costs assigned to load following.

7. Sum the costs from steps $3,4,5$, and 6 .

8. Divide the amount from step 7 by the amount of generating capacity from step 2 . The result, in $\$ / \mathrm{kW}$-year, is the annual cost of load following. 



\section{UTILITY-SPECIFIC RESULTS}

\section{AMERICAN ELECTRIC POWER}

The costs to AEP for G\&T scheduling and dispatch totaled $\$ 10.0$ million in 1993, equivalent to $\$ 0.04 / \mathrm{kW}$-month, close to the $\$ 0.05 / \mathrm{kW}$-month that AEP estimated. Although AEP includes these costs in its basic transmission tariff, we split them out here (Table 3 ).

AEP maintains $6 \%$ operating reserves to meet its regional-reliability council (East Central Area Reliability Coordination Agreement) responsibilities, which it splits evenly between load following and system protection. Its cost of these generating reserves is $\$ 6.07 / \mathrm{kW}$-month. (We split this $6 \%$ reserve among load-following, reliability, and supplemental-operating reserves $50 \%, 25 \%$, and $25 \%$.)

AEP estimates real losses at $3.6 \%$ and charges customers for both the capacity and energy associated with these losses. The capacity charge for losses is $\$ 10.83 / \mathrm{kW}$-month based on the maximum hourly demand each month, and the energy charge is based on AEP's average cost of energy $(1.55 \notin / \mathrm{kWh}$ in 1994$)$.

AEP's schedule of charges for energy imbalance is complicated, as is true for several other utilities. AEP defines on-peak times (the daily 16-hour period between 7 am and $11 \mathrm{pm}$ Ohio time for all days except Sundays and certain holidays) and off-peak times (all other hours). Hourly energy imbalances that fall within FERC's $1.5 \%$ deadband can be returned in kind during like (on- or off-peak) time periods within two months of occurrence. When a customer receives more energy than scheduled during an hour and that amount falls outside the deadband, AEP will charge 10 $/ \mathrm{kWh}$ for that energy. If, on the other hand, the customer receives less energy than scheduled, AEP will pay for that amount at its current hourly system lambda (shortrun marginal cost), which is approximately $1.55 \notin / \mathrm{kWh}$, averaged over the year.

AEP's charge for reactive power is based on its cost for generating capacity (including a $20 \%$ reserve margin) of $\$ 9.36 / \mathrm{kW}$-month. ${ }^{*}$ AEP calculates that $1.2 \%$ of its generating-unit costs are required for reactive power ( $21 \%$ of the generator and excitor system plus $21 \%$ of accessory electric equipment). These numbers lead to the $\$ 0.11 / \mathrm{kW}$-month charge for reactive

This $\$ 9.36 / \mathrm{kW}$-month charge differs from the $\$ 6.07 / \mathrm{kW}$-month charge for reserves because the latter charge excludes AEP's nuclear units, which are not used to provide operating reserves. Also, the $\$ 9.36 / \mathrm{kW}$ charge includes a $20 \%$ reserve. 
power shown in Table 3. Although AEP includes this charge in its basic transmission tariff, we break it out here.

AEP's total cost for ancillary services is $0.33 \phi / \mathrm{kWh}, 11 \%$ of its G\&T costs. Real-power losses dominate ancillary service, accounting for almost half of the total. Operating reserves account for more than one-fourth of the total, and energy imbalance (assuming an average 1\% deviation outside the deadband) accounts for $13 \%$.

Table 3. Ancillary-service prices for American Electric Power ${ }^{\mathbf{a}}$

\begin{tabular}{|c|c|c|c|c|}
\hline \multirow[b]{2}{*}{ Service } & \multirow[b]{2}{*}{ Price } & \multirow{2}{*}{$\begin{array}{l}\text { Price in } \\
\phi / \mathrm{kWh}\end{array}$} & \multicolumn{2}{|c|}{ Price as percentage of } \\
\hline & & & $\begin{array}{c}\text { Total AS } \\
\text { cost }\end{array}$ & G\&T cost \\
\hline Scheduling \& dispatch & $\$ 0.05 / \mathrm{kW}$-month & 0.013 & 3.8 & 0.4 \\
\hline Load following & $\$ 6.07 / \mathrm{kW}$-month & 0.046 & 14.0 & 1.6 \\
\hline Reliability reserve & $\$ 6.07 / \mathrm{kW}$-month & 0.023 & 7.0 & 0.8 \\
\hline Supplemental reserve & $\$ 6.07 / \mathrm{kW}$-month & 0.023 & 7.0 & 0.8 \\
\hline Energy imbalance & $8.45 \notin / \mathrm{kWh}$ & 0.042 & 12.8 & 1.5 \\
\hline \multicolumn{5}{|l|}{ Real losses } \\
\hline Demand & $\$ 10.83 / \mathrm{kW}-$ month & 0.099 & 30.0 & 3.4 \\
\hline Energy & $1.55 \notin / \mathrm{kWh}$ & 0.056 & 16.9 & 1.9 \\
\hline Voltage control & $\$ 0.11 / \mathrm{kW}$-month & 0.028 & 8.5 & 1.0 \\
\hline Total & & 0.331 & 100.0 & 11.5 \\
\hline
\end{tabular}

Sources: AEP (1995) and Pasternack (1995).

aEP's G\&T cost and load factor are $2.89 \notin / \mathrm{kWh}$ and 0.54 .

\section{COMMONWEALTH EDISON}

ComEd spent $\$ 5.1$ million on generation scheduling and dispatch plus $\$ 4.9$ million on transmission scheduling and dispatch in 1993 . Normalizing the total by its annual requirements sales of 82.8 GWh yields an implicit scheduling and dispatch charge of $0.012 \phi / \mathrm{kWh}$ (Table 4).

In accordance with the operating-reserve requirements of the Mid-American Interconnected Network, ComEd maintains regulating margin of $150 \mathrm{MW}$, additional spinning reserve of $185 \mathrm{MW}$, and additional nonspinning reserve of $188 \mathrm{MW}$, for a total operating reserve of $523 \mathrm{MW}$. Normalized by ComEd's peak demand of $17,800 \mathrm{MW}$, these reserves are equivalent to $0.84 \%$ for regulation plus $1.0 \%$ for spinning and $1.1 \%$ for nonspinning reserves. These $523-\mathrm{MW}$ of reserves (2.9\% of peak) are all required to be available within 10 minutes. The charges for spinning reserve include both demand and energy components. The energy 
component applies only when the customer actually uses this capacity (i.e., when its suppliers experience unexpected outages); we assumed a $10 \%$ forced-outage rate for this charge.

Table 4. Ancillary-service prices for Commonwealth Edison ${ }^{\text {a }}$

\begin{tabular}{|c|c|c|c|c|}
\hline \multirow[b]{2}{*}{ Service } & \multirow[b]{2}{*}{ Price } & \multirow{2}{*}{$\begin{array}{l}\text { Price in } \\
\notin / \mathrm{kWh}\end{array}$} & \multicolumn{2}{|c|}{ Price as percentage of } \\
\hline & & & $\begin{array}{c}\text { Total AS } \\
\text { cost }\end{array}$ & G\&T cost \\
\hline Scheduling \& dispatch & $\$ 10.0$ million & 0.012 & 4.3 & 0.2 \\
\hline Load following & $\$ 7.33 / \mathrm{kW}$-month & 0.016 & 5.7 & 0.3 \\
\hline \multicolumn{5}{|l|}{ Reliability reserve } \\
\hline Demand & $\$ 8.14 / \mathrm{kW}-$ month & 0.044 & 15.7 & 0.8 \\
\hline Energy & $0.2 \notin / \mathrm{kWh}$ & 0.020 & 7.1 & 0.4 \\
\hline Supplemental reserve & -- & -- & & \\
\hline Energy imbalance & $5.33 \notin / \mathrm{kWh}$ & 0.053 & 19.0 & 1.0 \\
\hline \multicolumn{5}{|l|}{ Real losses } \\
\hline Demand & $\$ 12.26 / \mathrm{kW}$-month & 0.085 & 30.3 & 1.6 \\
\hline Energy & $2.2 \notin / \mathrm{kWh}$ & 0.051 & 18.0 & 1.0 \\
\hline Voltage control & $\cdots$ & -- & & \\
\hline Total & & 0.281 & 100.0 & 5.4 \\
\hline
\end{tabular}

Sources: ComEd (1995) and Naumann (1995).

${ }^{a}$ ComEd's G\&T cost and load factor are $5.19 \notin / \mathrm{kWh}$ and 0.53 . ComEd did not include separate charges for supplemental-operating reserve or for voltage control.

ComEd proposed a complicated set of charges for energy imbalances outside a $2 \%$ deadband. As the amounts of over- or under-generation increase beyond the deadband, ComEd's charges also increase. For example, ComEd will purchase over-generation amounts between 2 and $5 \%$ at $90 \%$ of its avoided out-of-pocket cost with a cap of $1.4 \notin / \mathrm{kWh}$ during onpeak periods and $0.8 \notin / \mathrm{kWh}$ during offpeak periods. If the over-generation is greater than $5 \%$, ComEd will pay $50 \%$ of its avoided out-of-pocket cost with a cap of $0.7 \notin / \mathrm{kWh}$ during onpeak periods and $0.4 \notin / \mathrm{kWh}$ during offpeak periods. The rationale for this sliding scale is that customer use of ComEd's generating capacity increases as the deviations from scheduled deliveries increase beyond the allowed bandwidth. ComEd also proposes an unauthorized use charge of $30 \notin / \mathrm{kWh}$ for under-generation that exceeds $5 \%$ of the scheduled hourly amounts.

ComEd's charges for losses are split into demand and energy components, with average demand and energy loss factors of 2.7 and $2.3 \%$, respectively. The capacity charge for losses is the same as that for spinning reserve, and the energy charge is equal to $110 \%$ of ComEd's out-of-pocket cost. 
ComEd includes voltage support in its basic transmission charge, not as a separate ancillary service.

ComEd's total cost for ancillary services is $0.28 \notin / \mathrm{kWh}, 5 \%$ of its G\&T cost. Losses account for almost $50 \%$ of the total cost, and reserves account for almost $30 \%$.

\section{CONSUMERS POWER}

As part of the Michigan Public Service Commission (1995) retail-wheeling experiment, $\mathrm{CPCo}$, as well as several other parties to the case, proposed charges for various ancillary services. The results presented here for CPCo (Table 5) and for Detroit Edison (Table 6) are based on the Commission's order, rather than on the utility proposals.

The Commission allowed a monthly customer service charge that implicitly includes the costs of scheduling and dispatch. We divided CPCo's annual costs of G\&T scheduling and dispatch $(\$ 8.4$ million) by its annual requirements sales $(34.1 \mathrm{GWh})$ to obtain an estimated charge of $0.025 \notin / \mathrm{kWh}$.

The Commission approved a charge for operating reserves of $\$ 0.46 / \mathrm{kW}$-month plus $0.053 \phi / \mathrm{kWh}$. The company had proposed a slightly higher demand charge but no energy charge for operating reserves. The Commission recognized that the Michigan utilities assign about $6 \%$ of peak demand to operating reserves, split equally between spinning and supplemental reserves.

The Commission included three services related to discrepancies between actual and scheduled deliveries: deadband service, standby service, and unauthorized-use charges. The Commission approved a charge of $10 \notin / \mathrm{kWh}$ for deadband service. The order was unclear on utility payment if the customer over-generates. We assumed a zero payment for overgeneration.

The Commission approved a two-part charge for real losses. The demand component was set at $\$ 0.13 / \mathrm{kW}$-month per one percentage of line loss. For an assumed $3 \%$ line loss, the charge would be $\$ 0.39 / \mathrm{kW}$-month. The energy component was set at the system average cost of energy, roughly $1.7 \notin / \mathrm{kWh}$.

The Commission approved a charge for reactive support of $\$ 0.11 / \mathrm{kW}$-month, equal to the utility's proposal for voltage support and control.

The total cost of ancillary services for CPCo is $0.44 \notin / \mathrm{kWh}, 10 \%$ of total G\&T costs. Operating reserves account for about one-third of the total cost. Real power losses account for $30 \%$ of the total. 
Table 5. Ancillary-service prices for Consumers Power ${ }^{2}$

\begin{tabular}{|c|c|c|c|c|}
\hline \multirow[b]{2}{*}{ Service } & \multirow[b]{2}{*}{ Price } & \multirow{2}{*}{$\begin{array}{l}\text { Price in } \\
\phi / k W h\end{array}$} & \multicolumn{2}{|c|}{ Price as percentage of } \\
\hline & & & $\begin{array}{c}\text { Total AS } \\
\text { cost }\end{array}$ & G\&T cost \\
\hline Scheduling \& dispatch & $\$ 8.42$ million & 0.025 & 5.6 & 0.6 \\
\hline \multicolumn{5}{|l|}{ Operating reserves ${ }^{b}$} \\
\hline Demand & $\$ 0.46 / \mathrm{kW}$-month & 0.101 & 22.7 & 2.4 \\
\hline Energy & $0.053 \notin / \mathrm{kWh}$ & 0.053 & 11.9 & 1.2 \\
\hline Energy imbalance & $10 \notin / \mathrm{kWh}+\$ 50 / \mathrm{kW}$ & 0.105 & 23.6 & 2.5 \\
\hline \multicolumn{5}{|l|}{ Real losses } \\
\hline Demand & $\$ 0.39 / \mathrm{kW}$-month & 0.085 & 19.2 & 2.0 \\
\hline Energy & $1.73 \notin / \mathrm{kWh}$ & 0.052 & 11.7 & 1.2 \\
\hline Voltage control & $\$ 0.11 / \mathrm{kW}$-month & 0.024 & 5.4 & 0.6 \\
\hline Total & & 0.444 & 100.0 & 10.4 \\
\hline
\end{tabular}

Source: Michigan Public Service Commission (1995).

${ }^{\mathrm{a}} \mathrm{CPCo}$ 's G\&T cost and load factor are $4.27 \notin / \mathrm{kWh}$ and 0.63 .

boperating reserves include load following, reliability reserve, and supplementaloperating reserve.

\section{DETROIT EDISON}

Here, too, we rely on the Michigan Public Service Commission's (1995) order for estimates of ancillary-service costs. Because the categories and types of charges are almost the same as those for Consumers Power, we discuss only the significant difference.

The Commission approved a $\$ 0.30 / \mathrm{kW}$-month charge for voltage support. This results in a $0.074 \notin / \mathrm{kWh}$.

The total cost of ancillary services for $\mathrm{DE}$ is $0.50 \notin / \mathrm{kWh}, 10 \%$ of total G\&T costs (Table 6). Losses and operating reserves are the two largest components, with each accounting for about $30 \%$ of ancillary-services costs. Voltage support and reactive support account for most of the remaining costs.

\section{DUKE POWER}

Duke's investment in its system operating center is $\$ 37.9$ million. Its annual revenue requirements for the center is $\$ 5.7$ million. Normalized by Duke's system peak transmission demand of $16,300 \mathrm{MW}$, the cost for generation and transmission scheduling and dispatch is $\$ 0.03 / \mathrm{kW}$-month (Table 7). 
Table 6.

Ancillary-service prices for Detroit Edison ${ }^{\text {a }}$

\begin{tabular}{lrccc}
\hline Service & Price & $\begin{array}{l}\text { Price in } \\
\phi / \mathrm{kWh}\end{array}$ & \multicolumn{2}{c}{ Price as percentage of } \\
\cline { 5 - 5 } & & & $\begin{array}{c}\text { Total AS } \\
\text { cost }\end{array}$ & G\&T cost \\
\hline Scheduling \& dispatch & $\$ 0.05 / \mathrm{kW}$-month & 0.012 & 2.5 & 0.3 \\
Operating reserves & & & & \\
Demand & $\$ 0.38 / \mathrm{kW}$-month & 0.094 & 18.7 & 1.9 \\
Energy & $0.053 \notin / \mathrm{kWh}$ & 0.053 & 10.6 & 1.1 \\
Energy imbalance & $10 \notin / \mathrm{kWh}+\$ 50 / \mathrm{kW}$ & 0.112 & 22.3 & 2.3 \\
Real losses & & & & \\
Demand & $\$ 0.43 / \mathrm{kW}$-month & 0.106 & 21.2 & 2.2 \\
Energy & $0.05 \notin / \mathrm{kWh}$ & 0.050 & 10.0 & 1.0 \\
Voltage control & $\$ 0.30 / \mathrm{kW}$-month & 0.074 & 14.8 & 1.5 \\
$\quad$ Total & & 0.501 & 100.0 & 10.4 \\
\hline
\end{tabular}

Sources: Michigan Public Service Commission (1995) and Sammut (1995).

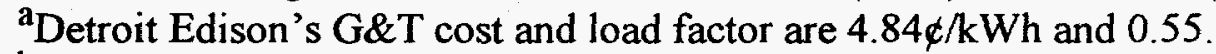

${ }^{b}$ Operating reserves include load following, reliability reserve, and supplementaloperating reserve.

Duke assigns $344 \mathrm{MW}$ to load following, at an estimated cost of $\$ 44.0 / \mathrm{kW}$-year for the units that provide this service. Adjusting for the $3 \%$ loss factor yields a cost of $\$ 0.08 / \mathrm{kW}$-month for load following.

Duke assigns $529 \mathrm{MW}$ of generating capacity to reliability reserves, equal to $3.2 \%$ of peak demand. With revenue requirements of $\$ 55.4 / \mathrm{kW}$-year for the five units that provide reserves, the cost of reliability reserves is $\$ 0.15 / \mathrm{kW}$-month. Duke has no separate charge for supplemental operating reserves; the company believes that any backup beyond the 10 minutes included in the $\$ 0.15 / \mathrm{kW}$-month charge could be negotiated separately as standby service or based on emergency-power charges.

Duke's deficit energy is the same as FERC's energy imbalance, except that Duke allows no deadband in its service. Duke charges $110 \%$ of its incremental energy cost, which averaged $2.6 \% / \mathrm{kWh}$ in 1994 . We increased the energy-imbalance amount to $2.5 \%$ (from the $1.0 \%$ used with the other utilities in this sample) to reflect the lack of deadband.

Duke assumes a $3 \%$ average real-power loss and charges separately for demand and energy losses. Its demand charge is based on the cost of a combustion turbine $(\$ 4.20 / \mathrm{kW}$ month). Energy losses are charged at $110 \%$ of Duke's hourly incremental energy cost. 
Duke determined, based on the production of real and reactive power during summer peak periods, that $4.1 \%$ of its generating capacity is used (essentially an opportunity cost) to produce reactive power. This determination led to a charge of $\$ 0.41 / \mathrm{kW}$-month for dynamic reactive-power support. Duke does not charge separately for the static reactive support provided by its transmission system; these costs are included in transmission rates.

Duke's total cost for ancillary services is $0.30 \notin / \mathrm{kWh}, 9 \%$ of its G\&T costs. Realpower losses dominate ancillary service, accounting for more than one-third of the total cost. Reactive power is the second most costly service, accounting for almost one-third of the total.

Table 7. Ancillary-service prices for Duke Power ${ }^{a}$

\begin{tabular}{lrccc}
\hline Service & Price & $\begin{array}{l}\text { Price in } \\
\phi / \mathrm{kWh}\end{array}$ & $\begin{array}{c}\text { Price as percentage of } \\
\text { Total AS } \\
\text { cost }\end{array}$ & G\&T cost \\
\hline Scheduling \& dispatch & $\$ 0.03 / \mathrm{kW}$-month & 0.007 & 2.3 & 0.2 \\
Load following & $\$ 0.08 / \mathrm{kW}$-month & 0.018 & 6.0 & 0.5 \\
Reliability reserve & $\$ 0.15 / \mathrm{kW}$-month & 0.034 & 11.3 & 1.0 \\
Supplemental reserve & --- & -- & & \\
Energy imbalance & $2.86 \notin / \mathrm{kWh}$ & 0.036 & 11.7 & 1.0 \\
Real losses & & & & \\
$\quad$ Demand & $\$ 4.2 / \mathrm{kW}$-month & 0.029 & 9.5 & 0.8 \\
$\quad$ Energy & $2.86 \notin / \mathrm{kWh}$ & 0.086 & 28.2 & 2.5 \\
Voltage control & $\$ 0.41 / \mathrm{kW}$-month & 0.094 & 31.0 & 2.7 \\
$\quad$ Total & & 0.304 & 100.0 & 8.7 \\
\hline
\end{tabular}

Sources: Duke Power Company (1995) and Burnett (1995).

${ }^{a}$ Duke's G\&T cost and load factor are 3.50\&/kWh and 0.60. Duke did not include a charge for supplemental-operating reserve.

\section{GENERAL PUBLIC UTILITIES}

GPU uses a MW-mile approach to allocate most of its costs among users of its transmission system. This reflects the fact that most costs are based on both the amount of power being transmitted and the distance it is being moved. Administrative, billing, and scheduling expenses are the notable exceptions; these costs are allocated based on the number of transactions.

GPU's costs for G\&T scheduling and dispatch totaled $\$ 18.9$ million in 1993. Spread across its requirements sales of $45.5 \mathrm{GWh}$, the cost for scheduling and dispatch is $0.042 \notin / \mathrm{kWh}$. 
GPU charges transmission customers a fixed monthly fee plus a charge for each schedule change. Because the charges are designed to recover actual costs, we used the aggregate number spread across all sales.

GPU's capacity requirements for load following (regulation) are determined by the PJM Interconnnection Association and are currently $0.22 \%$ of the forecast PJM load. GPU's total cost of regulation was $\$ 6.81$ million for 1993 , or $0.015 \notin / \mathrm{kWh}$.

GPU maintains $5 \%$ operating reserves to meet its regional-reliability council (MidAtlantic Area Council) responsibilities. Its cost of these generating reserves is $\$ 10.11 / \mathrm{kW}$ month. This results in a charge for operating reserves (the sum of reliability and supplemental reserves) of $0.116 \notin / \mathrm{kWh}$. The regional transmission grid is often constrained because of high west-to-east power transfers. For transactions into or through the PJM system from the west or north, GPU requires an additional $40 \%$ reserve (its reliability-impact charge) to replace the emergency support that the intertied transmission system would otherwise have provided to GPU. This adds $0.93 \notin / \mathrm{kWh}$ to the cost of generator reserves and shows how dramatically costs can rise when a system is constrained.

GPU charges for real power losses include both capacity and energy at the same $3.0 \%$. The capacity charge is $\$ 10.11 / \mathrm{kW}$-month based on the maximum hourly demand, and the energy charge is based on GPU's average cost of energy $(2.50 \mathrm{k} / \mathrm{kWh}$ in 1994).

GPU does not use a deadband for its energy imbalance charge. GPU pays for excess energy (over-generation) at $90 \%$ of its hourly incremental cost. GPU charges for excess consumption (under-generation) at its hourly cost plus a daily demand charge. Both the energy charge and the daily demand charge are consistent with GPU's normal prices and, therefore, do not represent a penalty. In other words, customer charges for energy imbalance are consistent with what they would pay for the basic generating capacity and energy.

GPU recovers the costs of the transmission system's reactive power requirements through four separate charges. The capacitor charge recovers the capital cost of cspacitors installed solely to support the transmission system, $\$ 0.84$ million/month. Spreading this cost across the GPU peak demand of $8716 \mathrm{MW}$ results in a $\$ 0.096 / \mathrm{kW}$-month charge.

The production VAR charge recovers GPU's capital cost for the portion of its generating plants used to supply reactive power to the transmission system, $\$ 1.94 \mathrm{million} / \mathrm{month}$ or $\$ 0.222 / \mathrm{kW}$-month.

GPU includes a VAR energy-loss charge to recover the variable energy costs of the portion of real losses incurred by generators to supply reactive power. GPU loses $1.08 \mathrm{MW}$ on average in production of reactive power. We valued this energy at GPU's average system incremental production cost. This results in a very low charge of $0.00005 \notin / \mathrm{kWh}$. 
Table 8. Ancillary-service prices for General Public Utilities ${ }^{\text {a }}$

\begin{tabular}{|c|c|c|c|c|}
\hline \multirow[b]{2}{*}{ Service } & \multirow[b]{2}{*}{ Price } & \multirow{2}{*}{$\begin{array}{l}\text { Price in } \\
\not / \mathrm{kWh}\end{array}$} & \multicolumn{2}{|c|}{ Price as percentage of } \\
\hline & & & $\begin{array}{c}\text { Total AS } \\
\text { cost }\end{array}$ & G\&T cost \\
\hline $\begin{array}{l}\text { Scheduling \& } \\
\text { dispatch }\end{array}$ & $\begin{array}{l}\$ 600 / \text { month }+ \\
\$ 10 \text { to } \$ 35 / \text { transaction }\end{array}$ & 0.042 & 10.5 & 0.8 \\
\hline Load following & $0.015 \phi / \mathrm{kWh}$ & 0.015 & 3.8 & 0.3 \\
\hline Operating reserves & $\$ 10.11 / \mathrm{kW}-$ month & 0.116 & 29.4 & 2.4 \\
\hline Energy imbalance & $\begin{array}{r}90 \% \text { payment for over- } \\
\text { delivery, } 100 \% \text { payment } \\
\text { for under-delivery }\end{array}$ & 0.003 & 0.8 & 0.1 \\
\hline \multicolumn{5}{|l|}{ Real losses } \\
\hline Demand & $\$ 10.11 / \mathrm{kW}$-month & 0.070 & 17.7 & 1.4 \\
\hline Energy & $2.50 \notin / \mathrm{kWh}$ & 0.075 & 19.0 & 1.5 \\
\hline Voltage control & $\$ 0.32 / \mathrm{kW}$-month & 0.074 & 18.6 & 1.5 \\
\hline Total & & 0.394 & 100.0 & 8.0 \\
\hline
\end{tabular}

Sources: GPU(1995) and Funes (1996).

${ }^{a}$ GPU's G\&T cost and load factor are $4.94 \notin / \mathrm{kWh}$ and 0.60 . GPU does not consider its reliability-impact charge (equivalent to $0.930 \notin / \mathrm{kWh}$ ) an ancillary service; therefore it is not included in this table.

Finally, GPU includes a VAR capacity-loss charge to recover the cost of lost real generating capacity caused by the production of reactive power. This lost capacity totals 1.87 MW for the GPU native load. Spread over its peak demand of $8716 . \mathrm{MW}$ and priced at $\$ 10.11 / \mathrm{kW}$-month, this cost results in another low charge of $0.0005 \phi / \mathrm{kWh}$. The total cost of voltage support, the sum of these four charges, is equivalent to $0.074 \notin / \mathrm{kWh}$; the first two charges account for $99.3 \%$ of the total charge for voltage support.

GPU has an off-cost generation charge, which allocates the cost of running generating units out of merit order to relieve transmission constraints. Because this charge is very case specific, we did not include it in Table 8. GPU also has an extra-high-voltage overuse charge that results from the use of jointly owned extra-high voltage lines in the PJM Interconnection. Because the charge involves both credits and charges, it should net to zero when all owners and customers are considered.

GPU's total cost for ancillary services is $0.39 \notin / \mathrm{kWh}, 8 \%$ of its G\&T cost. Losses account for over one third of the total, operating reserves for just under a third, and voltage control for almost $20 \%$. For transactions that adversely affect the ability to use the PJM ties 
with its neighboring systems in place of generating reserves, the reliability impact charge is nearly 2.5 times the total ancillary-service charge.

\section{ILLINOIS POWER}

IP includes the costs for G\&T scheduling and dispatch in its basic transmission-service rate. In 1993, IP spent $\$ 1.01$ million for system control and load dispatch plus $\$ 0.71$ million for transmission dispatch. Normalizing by requirements sales of $23.3 \mathrm{GWh}$ yields a cost of $0.007 \notin / \mathrm{kWh}$ for scheduling and dispatch (Table 9).

IP adopted FERC's 3\% loss figure. If IP supplies the losses, it charges for both capacity and energy. The energy charge is $110 \%$ of IP's incremental cost. For 1993, this would have resulted in an average energy charge for losses of $0.057 \% / \mathrm{kWh}$. The capacity charge is the company's generation capacity charge for losses $(\$ 0.486 / \mathrm{kW}-\mathrm{month})$ times the customer's maximum hourly demand for the month.

IP adopted FERC's treatment of energy imbalance. Energy imbalances within the $1.5 \%$ deadband are compensated for by returning energy inkind or paid for at IP's incremental cost (if the customer takes more energy than the supplier delivers) or decremental cost (if the customer takes less energy than the supplier delivers) at the time of the over- or under-delivery. All undergeneration imbalances beyond the deadband are charged $10 \notin / \mathrm{kWh}$ to provide an incentive to minimize energy imbalances.

In a March 1995 filing with FERC, IP set its charge for load-following reserve at $\$ 0.103 / \mathrm{kW}$-month and for frequency regulation at $\$ 0.112 / \mathrm{kW}$-month, totaling $\$ 0.215 / \mathrm{kW}$ month. Reliability reserves were set at $\$ 0.133 / \mathrm{kW}$-month, and supplemental reserve at $\$ 0.072 / \mathrm{kW}-$ month.

IP's total cost for ancillary services is $0.30 \notin / \mathrm{kWh}, 7 \%$ of its G\&T cost. Replacement of real losses accounts for almost $50 \%$ of the total cost. The combination of load following, system protection, and voltage support accounts another third. Energy imbalance accounts for the remainder.

*IP allows the use of dynamic scheduling when this is feasible and reliable. Rates to cover the additional cost of dynamic scheduling will be negotiated if a customer wishes to employ dynamic scheduling.

\#In its revised filing of August 1995, IP combined load following, system protection, and voltage control into a bundle with a combined price of $0.1 \mathrm{k} / \mathrm{kWh}$, as suggested by FERC in its pro forma tariffs. We used IP's earlier filing as the basis for Table 9 because of the additional detail it provided. Perhaps coincidentally, the IP cost of these three services is almost exactly equal to FERC's $0.1 \mathrm{c} / \mathrm{kWh}$. 
Table 9. Ancillary-service prices for Illinois Power $^{\mathbf{a}}$

\begin{tabular}{|c|c|c|c|c|}
\hline \multirow[b]{2}{*}{ Service } & \multirow[b]{2}{*}{ Price } & \multirow{2}{*}{$\begin{array}{l}\text { Price in } \\
\notin / \mathrm{kWh}\end{array}$} & \multicolumn{2}{|c|}{ Price as percentage of } \\
\hline & & & $\begin{array}{c}\text { Total AS } \\
\text { cost }\end{array}$ & G\&T cost \\
\hline Scheduling \& dispatch & $\$ 1.72$ million & 0.007 & 2.5 & 0.2 \\
\hline Load following & $0.215 \$ / \mathrm{kW}$-month & 0.037 & 12.3 & 0.8 \\
\hline Reliability reserve & $0.133 \$ / \mathrm{kW}$-month & 0.023 & 7.6 & 0.5 \\
\hline Supplemental reserve & $0.072 \$ / \mathrm{kW}$-month & 0.012 & 4.1 & 0.3 \\
\hline Energy imbalance & $10.0 \notin / \mathrm{kWh}$ & 0.050 & 16.7 & 1.1 \\
\hline \multicolumn{5}{|l|}{ Real losses } \\
\hline Demand & $\$ 0.486 / \mathrm{kW}$-month & 0.086 & 28.5 & 1.9 \\
\hline Energy & $0.057 \notin / \mathrm{kWh}$ & 0.057 & 19.0 & 1.3 \\
\hline Voltage control & $\$ 6.63$ million & 0.028 & 9.3 & 0.6 \\
\hline Total & & 0.300 & 100.0 & 6.6 \\
\hline
\end{tabular}

Sources: Illinois Power Company (1995) and Shipp (1995).

'IP's G\&T cost and load factor are $4.54 \notin / \mathrm{kWh}$ and 0.78 .

\section{NORTHEAST UTILITIES}

NU calculates separate charges for generation scheduling and dispatching and transmission scheduling and dispatching. Together, the charge for the two services totals $\$ 0.138 / \mathrm{kW}$-month (Table 10).

NU's charge for load following does not include a capacity component. The energy charge for this service is equal to a negotiated rate up to $10 \% / \mathrm{kWh}$ "times the maximum variation in a wheeling customer's load during each hour of a month." This maximum variation is the difference between scheduled and actual load over a particular time period, with the appropriate time period based on the type of metering at the customer's location. This variation is then averaged over each one-hour period to convert from a change in power level to an energy level. For purposes of this analysis, we assumed that this intrahour variation would average $0.5 \%$, yielding a charge for load following of $0.05 \notin / \mathrm{kWh}$.

In accordance with the reserve criteria adopted by the Northeast Power Coordinating Council, NU maintains an operating reserve of $11 \%$, which covers both reliability and supplemental-operating reserves. The charge for this reserve is capped at $\$ 7.30 / \mathrm{kW}$-month plus $110 \%$ of the NU system incremental cost for energy supplied as operating reserve. 
NU's definition of energy imbalance parallels FERC's. NU proposes the same $1.5 \%$ deadband within which energy is returned inkind. Outside the deadband, NU charges a negotiated rate up to $10 \notin / \mathrm{kWh}$ for energy supplied by NU. If the customer over-generates, NU will pay the wheeling customer $90 \%$ of the NU system decremental cost.

Table 10. Ancillary-service prices for Northeast Utilities ${ }^{\text {a }}$

\begin{tabular}{lrrcc}
\hline Service & \multicolumn{1}{c}{ Price } & $\begin{array}{l}\text { Price in } \\
\phi / \mathrm{kWh}\end{array}$ & \multicolumn{2}{c}{ Price as percentage of } \\
& & & $\begin{array}{c}\text { Total AS } \\
\text { cost }\end{array}$ & G\&T cost \\
\hline Scheduling \& dispatch & $\$ 0.138 / \mathrm{kW}$-month & 0.030 & 6.7 & 0.5 \\
Load-following & $10 \notin / \mathrm{kWh}$ & 0.050 & 11.3 & 0.9 \\
Operating reserves & & & & \\
Demand & $\$ 7.30 / \mathrm{kW}$-month & 0.174 & 39.4 & 3.2 \\
Energy & $0.27 \notin / \mathrm{kWh}$ & 0.027 & 6.1 & 0.5 \\
Energy imbalance & $7.6 \notin / \mathrm{kWh}$ & 0.038 & 8.6 & 0.7 \\
Real losses & & & & \\
$\quad$ Demand & $\$ 7.30 / \mathrm{kW}$-month & 0.043 & 9.7 & 0.8 \\
Energy & $2.97 \notin / \mathrm{kWh}$ & 0.080 & 18.2 & 1.5 \\
Voltage control & --- & -- & & \\
$\quad$ Total & & 0.441 & 100.0 & 8.0 \\
\hline
\end{tabular}

Sources: Northeast Utilities (1995) and Psoter (1995).

'NU's G\&T cost and load factor are $5.5 \notin / \mathrm{kWh}$ and 0.63 . NU did not estimate a separate charge for voltage control.

NU breaks its charges for losses into demand and energy components. The demand charge is $\$ 7.30 / \mathrm{kW}$-month, and the energy charge is equal to $110 \%$ of the NU system incremental cost (about $2.7 \notin / \mathrm{kWh}$ ). We applied these charges to the average loss at the bulkpower substation level of $2.7 \%$.

NU includes the cost of transmission-related voltage support in its basic transmission tariff. NU did not consider the cost of generation-related voltage support in its tariff.

NU's total cost for ancillary services is $0.44 \% / \mathrm{kWh}$ (excluding the cost for voltage control), equivalent to $8 \%$ of its G\&T costs. Operating (reliability plus supplemental-operating) reserves account for almost half the total cost. Losses account for about one-fourth. Load following, energy imbalance, and scheduling account for the remainder. 


\section{NORTHERN STATES POWER}

NSP includes system voltage control/VAR support in its basic transmission tariff and has not published the costs for these services separately.

For scheduling with voice or fax, NSP charges $\$ 1.82 /$ schedule-hour. The charge drops to $\$ 1.06 /$ schedule-hour if NSP's electronic data link is used. NSP's costs for G\&T scheduling and dispatch totaled $\$ 7.0$ million in 1993. Spread across its requirements sales of $41.0 \mathrm{GWh}$, the cost for scheduling and dispatch is $0.017 \mathrm{k} / \mathrm{kWh}$ (Table 11). Actual customer costs will vary depending on the number and size of schedules.

NSP charges $\$ 1.00 / \mathrm{kW}$-year for load following. This results in a charge of $0.019 \phi / \mathrm{kWh}$ based on its requirements sales and system load factor of 0.59 . The requirement for load following varies with system condition; typically, NSP assigns generation equal to about $1 \%$ of its load to this service.

NSP charges $\$ 3.74 / \mathrm{kW}$-month for spinning reserve. The amount of reserve is determined by the rules of the Mid-Continent Area Power Pool and is typically about $2.1 \%$ of NSP's demand. Supplemental-operating reserve requirements, for which NSP charges $\$ 0.60 / \mathrm{kW}$ month, are also about $2.1 \%$.

Real losses average $2.4 \%$ on the NSP system. They can be replaced in kind or purchased from NSP and are valued at the system marginal cost, which averages $1.04 \notin / \mathrm{kWh}$.

NSP's schedule of charges for energy imbalance is complicated, as is true for several other utilities. NSP uses a deadband of $4 \%$ with different charges between 4 and $6 \%$ and beyond $6 \%$. Additionally, NSP charges a higher rate during onpeak hours than during offpeak hours. For imbalances between 4 and $6 \%$ during onpeak hours, NSP charges $125 \%$ of its marginal cost of power or the allowable emergency rate (set at a minimum of $3.0 \mathrm{k} / \mathrm{kWh}$ ). NSP charges $110 \%$ of its marginal cost or the allowable emergency rate for such imbalances during offpeak hours. If the energy imbalance exceeds $6 \%$, the onpeak charge rises to $150 \%$ of system lambda or the emergency rate, and the offpeak charge is $125 \%$ of lambda or the emergency rate.

NSP's total cost for ancillary services is $0.10 \notin / \mathrm{kWh}$, equivalent to $3 \%$ of its G\&T cost (Table 11). Real-loss replacement accounts for one-fourth of the total cost, followed closely by load following, spinning reserve, scheduling and dispatch, and energy imbalance.

\section{PACIFICORP}

PacifiCorp estimates the costs for G\&T scheduling and dispatch as $\$ 13.0$ million a year. It normalizes this cost by the $6787 \mathrm{MW}$ of thermal generation, which results in a cost of $\$ 0.16 / \mathrm{kW}$-month (Table 12). 
Table 11. Ancillary-service prices for Northern States Power ${ }^{a}$

\begin{tabular}{lrccc}
\hline Service & \multicolumn{1}{c}{ Price } & $\begin{array}{c}\text { Price in } \\
\phi / \mathrm{kWh}\end{array}$ & $\begin{array}{c}\text { Price as percentage of } \\
\text { Total AS } \\
\text { cost }\end{array}$ & G\&T cost \\
\hline Scheduling \& dispatch & $\begin{array}{r}\$ 1.06 \text { to } \$ 1.82 / \\
\text { schedule-hour }\end{array}$ & 0.017 & 17.5 & 0.5 \\
Load following & $\$ 0.0833 / \mathrm{kW}$-month & 0.019 & 19.8 & 0.6 \\
Reliability reserve & $\$ 3.74 / \mathrm{kW}$-month & 0.019 & 19.0 & 0.6 \\
Supplemental reserve & $\$ 0.60 / \mathrm{kW}$-month & 0.003 & 3.0 & 0.1 \\
Energy imbalance & 110 to $150 \%$ lambda & 0.015 & 15.3 & 0.5 \\
Real losses & $1.04 \notin / \mathrm{kWh}$ & 0.025 & 25.4 & 0.8 \\
Voltage control & --- & -- & & \\
$\quad$ Total & & 0.098 & 100.0 & 3.1 \\
\hline
\end{tabular}

Sources: NSP (1995) and Grove (1996).

${ }^{a}$ NSP's G\&T cost and load factor are $3.20 \mathrm{k} / \mathrm{kWh}$ and 0.59 . NSP did not estimate a separate charge for voltage control.

Unless dynamic scheduling is used, PacifiCorp requires transmission customers to purchase or make available load-following capacity of at least $3.5 \%$ of the load. Based on a fixed cost of $\$ 12.20 / \mathrm{kW}$-month for the generators equipped with automatic generation control (which includes $\$ 33.50 / \mathrm{kW}$-year for transmission costs plus a 3\% adjustment for losses), the rate is $\$ 0.427 / \mathrm{kW}$-month. Because any energy associated with this service is already purchased through the energy-imbalance service, only a capacity charge is involved for load following.

PacifiCorp requires transmission customers to provide or purchase system-protection service for generation resources located within the PacifiCorp control area. PacifiCorp's charges the same $\$ 12.20 / \mathrm{kW}$-month for this service as for load following. Based on regional reliability council guidelines, PacifiCorp requires a 5\% reserve for hydro generation and a $7 \%$ reserve for thermal generation; Table 12 assumes a charge for system-protection capacity based on thermal generation.

PacifiCorp used FERC's $1.5 \%$ deadband for energy imbalance. If a customer takes energy outside the $1.5 \%$ deadband, a charge of $10 \notin / \mathrm{kWh}$ is imposed. When excess energy beyond the $1.5 \%$ deadband is unintentionally delivered to PacifiCorp, it will pay $1.37 \phi / \mathrm{kWh}$ for this energy. PacifiCorp will not pay for energy intentionally delivered to it beyond the $1.5 \%$ deadband.

Although PacifiCorp estimates that losses range from 3.9\% in its Utah Division to $5.3 \%$ in its Pacific Division, it agreed to accept FERC's 3\% loss figure as a common industry 
average. The company does not agree with FERC's pricing for loss compensation, however. PacifiCorp believes that the market for loss compensation should be competitive. It includes compensation for generation capacity as well as for energy losses. A transmission customer can provide the resources to compensate for losses or can purchase the service from PacifiCorp. When PacifiCorp provides this service, the rates are capped at the short-term firm rate of $\$ 19.18 / \mathrm{kW}$-month for capacity plus the short-term nonfirm rate of $1.37 \phi / \mathrm{kWh}$ for energy. These result in charges of $\$ 0.575 / \mathrm{kW}$-month for capacity plus $0.041 \mathrm{c} / \mathrm{kWh}$ for energy.

Table 12. Ancillary-service prices for PacifiCorp ${ }^{\text {a }}$

\begin{tabular}{lrrrr}
\hline Service & Price & $\begin{array}{l}\text { Price in } \\
\phi / \mathrm{kWh}\end{array}$ & $\begin{array}{c}\text { Price as percentage of } \\
\text { Total AS } \\
\text { cost }\end{array}$ & G\&T cost \\
\hline Scheduling \& dispatch & $\$ 0.16 / \mathrm{kW}$-month & 0.030 & 6.5 & 1.1 \\
Load following & $\$ 0.427 / \mathrm{kW}$-month & 0.081 & 17.3 & 2.9 \\
Operating reserves & $\$ 0.854 / \mathrm{kW}$-month & 0.161 & 34.7 & 5.8 \\
Energy imbalance & $8.6 \notin / \mathrm{kWh}$ & 0.043 & 9.3 & 1.6 \\
Real losses & & & & \\
Demand & $\$ 0.575 / \mathrm{kW}$-month & 0.109 & 23.4 & 3.9 \\
$\quad$ Energy & $0.041 \phi / \mathrm{kWh}$ & 0.041 & 8.8 & 1.5 \\
Voltage control & --- & --- & & \\
$\quad$ Total & & 0.465 & 100.0 & 16.8 \\
\hline
\end{tabular}

Sources: PacifiCorp (1995) and Stamper (1995).

a PacifiCorp's G\&T cost and load factor are $2.77 \phi / \mathrm{kWh}$ and 0.73. PacifiCorp did not estimate a separate cost for voltage control.

PacifiCorp's total cost for ancillary services is $0.47 \not / \mathrm{kWh}$, equivalent to $17 \%$ of its G\&T power cost. Operating reserves and load following account for half of the total cost. Real-power losses account for an additional one-third. Energy imbalance accounts for less than $10 \%$ of the total.

\section{PACIFIC GAS \& ELECTRIC}

PG\&E4 spent $\$ 6.39$ million in 1993 on scheduling and dispatch. Normalized by its requirements sales of $77.9 \mathrm{GWh}$, this is equivalent to $0.008 \not / \mathrm{kWh}$ (Table 13).

PG\&E maintains a regulating margin (what we call load following) of $400 \mathrm{MW}$, equivalent to $2.8 \%$ of its 1993 peak demand. At a cost of $\$ 5.58 / \mathrm{kW}$-month, regulation costs $0.034 \propto / \mathrm{kWh}$. 
PG\&E maintains total operating reserves of 15 to $20 \%$, of which about $7 \%$ is assigned to reliability (i.e., spinning plus fast-start). These generation reserves cost $\$ 4.07 / \mathrm{kW}$-month, equivalent to $0.063 \% / \mathrm{kWh}$. Supplemental reserves (assumed here to total $8 \%$ of peak demand) cost $\$ 4.93 / \mathrm{kW}$-month. The cost of supplemental reserves is higher than that for reliability reserves because a portion of the cost of the latter is reduced to reflect revenues collected from the load-following charge.

Table 13. Ancillary-service prices for Pacific Gas \& Electric ${ }^{\text {a }}$

\begin{tabular}{|c|c|c|c|c|}
\hline \multirow[b]{2}{*}{ Service } & \multirow[b]{2}{*}{ Price } & \multirow{2}{*}{$\begin{array}{l}\text { Price in } \\
e / \mathrm{kWh}\end{array}$} & \multicolumn{2}{|c|}{ Price as percentage of } \\
\hline & & & $\begin{array}{c}\text { Total AS } \\
\text { cost }\end{array}$ & G\&T cost \\
\hline Scheduling \& dispatch & $\$ 6.39$ million & 0.008 & 2.9 & 0.1 \\
\hline Load following & $\$ 5.58 / \mathrm{kW}$-month & 0.034 & 12.0 & 0.6 \\
\hline $\begin{array}{l}\text { Operating reserves } \\
\text { Reliability } \\
\text { Supplemental }\end{array}$ & $\begin{array}{l}\$ 4.07 / \mathrm{kW} \text {-month } \\
\$ 4.93 / \mathrm{kW} \text {-month }\end{array}$ & $\begin{array}{l}0.063 \\
0.087\end{array}$ & $\begin{array}{l}21.9 \\
30.3\end{array}$ & $\begin{array}{l}1.1 \\
1.5\end{array}$ \\
\hline $\begin{array}{l}\text { Energy imbalance } \\
\text { Demand } \\
\text { Energy }\end{array}$ & $\begin{array}{r}\$ 0.164 / \mathrm{kW} \text {-day } \\
2.65 \not / \mathrm{kWh}\end{array}$ & $\begin{array}{l}0.005 \\
0.013\end{array}$ & $\begin{array}{l}1.9 \\
4.6\end{array}$ & $\begin{array}{l}0.1 \\
0.2\end{array}$ \\
\hline Losses & $2.3 \phi / \mathrm{kWh}$ & 0.076 & 26.5 & 1.3 \\
\hline $\begin{array}{l}\text { Voltage control } \\
\text { Total }\end{array}$ & --- & 0.287 & 100.0 & 5.0 \\
\hline
\end{tabular}

Sources: Pacific Gas \& Electric (1994) and Yang (1995).

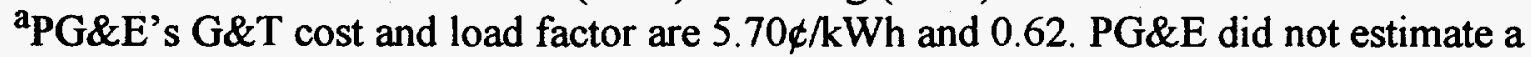
separate cost for voltage control.

PG\&E imposes demand and energy charges for energy imbalance. The demand charge is $\$ 0.164 / \mathrm{kW}$-day, and the energy charge is $115 \%$ of incremental cost (about $2.3 \notin / \mathrm{kWh}$ ). It is not clear whether PG\&E pays customers for over-generation; we assumed no such payments.

PG\&E's losses average 3\%. The charge for losses is based on $110 \%$ of PG\&E's average marginal cost, about 2.3 $₫ / \mathrm{kWh}$. PG\&E imposes no demand charge for losses.

In total, PG\&E's ancillary-services costs are $0.29 \notin / \mathrm{kWh}, 5 \%$ of G\&T costs. Operating reserves account for about $50 \%$ of the total, and losses for one-fourth. 


\section{SOUTHERN CALIFORNIA EDISON}

SCE calculated the cost of ancillary services on the basis of different sets of generating resources: all those available to the company, including independent power producers; SCEowned units only; and the SCE oil and gas units that generally operate on the margin. We based our estimates on the SCE-owned units only because these numbers fell between the other two sets (Table 14).

SCE spends $\$ 7.8$ million/year for scheduling and dispatch, equivalent to $0.01 \notin / \mathrm{kWh}$.

SCE assigns $1270 \mathrm{MW}$ to load following, equivalent to $7.7 \%$ of peak demand. It calculates the energy cost for these units at $1.2 \mathrm{MBtu} / \mathrm{MW}$ and $\$ 1.57 / \mathrm{MBtu}$ to get $\$ 21.0$ million/year. SCE adds $\$ 5.0$ million for annual labor and computer costs, which yields a total cost of $\$ 26$ million for load following. The energy charge for load following is therefore equivalent to $0.43 \notin / \mathrm{kWh}$. SCE computes no capacity charge for load following.

SCE's spinning reserve equals $7.0 \%$ of peak demand. This service has both demand and energy components. The demand component costs $\$ 9.06 / \mathrm{kW}$-month. The energy component, based on $670 \mathrm{MW}$ of generating capacity ( $4.1 \%$ of peak demand), is costed in the same manner as is load following, but without the labor and equipment charge, and is $0.348 \notin / \mathrm{kWh}$.

SCE considers planning reserves (equal to $9 \%$ of peak demand) an ancillary service with a cost of $\$ 9.06 / \mathrm{kW}$-month.

SCE did not include energy imbalance in its set of ancillary services.

At the transmission level, SCE's losses are $2.8 \%$ for demand and $2.7 \%$ for energy. Losses charges include both a capacity cost (the $\$ 9.06 / \mathrm{kW}$-month noted above) and an energy cost of $1.59 \notin / \mathrm{kWh}$.

SCE calculates the cost of generator-provided reactive power at $\$ 27$ million/year. Based on peak demand, the cost is $\$ 0.138 / \mathrm{kW}$-month.

Overall, SCE's cost of ancillary services is $0.57 \notin / \mathrm{kWh}$, almost $9 \%$ of G\&T costs. Reserves dominate these costs, accounting for almost three-fourths of the total. 
Table 14. Ancillary-service prices for Southern California Edison ${ }^{\text {a }}$

\begin{tabular}{|c|c|c|c|c|}
\hline \multirow[b]{2}{*}{ Service } & \multirow[b]{2}{*}{ Price } & \multirow{2}{*}{$\begin{array}{l}\text { Price in } \\
\not / \mathrm{kWh}\end{array}$} & \multicolumn{2}{|c|}{ Price as percentage of } \\
\hline & & & $\begin{array}{c}\text { Total AS } \\
\text { cost }\end{array}$ & G\&T cost \\
\hline Scheduling \& dispatch & $\$ 7.8$ million & 0.010 & 1.8 & 0.2 \\
\hline Load following & $0.431 \not / \mathrm{kWh}$ & 0.033 & 5.9 & 0.5 \\
\hline \multicolumn{5}{|l|}{ Spinning reserves } \\
\hline Demand & $\$ 9.06 / \mathrm{kW}$-month & 0.160 & 28.4 & 2.4 \\
\hline Energy & $0.348 \notin / \mathrm{kWh}$ & 0.014 & 2.5 & 0.2 \\
\hline Planning reserve & $\$ 9.06 / \mathrm{kW}$-month & 0.206 & 36.5 & 3.1 \\
\hline Energy imbalance & -- & --- & & \\
\hline \multicolumn{5}{|l|}{ Losses } \\
\hline Demand & $\$ 9.06 / \mathrm{kW}$-month & 0.064 & 11.3 & 1.0 \\
\hline Energy & $1.59 \notin / \mathrm{kWh}$ & 0.043 & 7.6 & 0.7 \\
\hline Voltage control & $\$ 0.138 / \mathrm{kW}$-month & 0.035 & 6.2 & 0.5 \\
\hline Total & & 0.565 & 100.0 & 8.6 \\
\hline
\end{tabular}

Source: Parker (1995).

${ }^{a}$ SCE's G\&T cost and load factor are $6.58 \notin / \mathrm{kWh}$ and 0.54 . SCE did not estimate a separate charge for energy imbalance. 


\section{OVERALL RESULTS}

As shown in Tables 3 through 14, the cost of ancillary services ranges from 0.10 to $0.57 \mathrm{k} / \mathrm{kWh}$ and from 3 to $17 \%$ of G\&T costs. However, these estimates do not adjust for the services not estimated by some of the utilities. In particular, three utilities did not estimate costs for supplemental-operating reserve, one utility did not estimate a cost for energy imbalance, and five did not estimate costs for system voltage control. Overall, $11 \%$ of the cost estimates were missing. We imputed values for these missing elements by assigning the average of the nonzero cost estimates for each service to the missing elements.

Including these changes, the cost of ancillary services ranges from 0.15 to $0.68 \phi / \mathrm{kWh}$ and from 5 to $25 \%$ of G\&T costs across these 12 utilities (Tables 15 and 16, Fig. 1). On average, ancillary services cost $0.41 \notin / \mathrm{kWh}$ and represent $10 \%$ of G\&T costs. The coefficient of variation (ratio of standard deviation to mean) for ancillary-service costs is 0.35 and for ancillary-service costs as a percentage of G\&T costs is 0.51 . This difference suggests that there is less variation in absolute than in relative costs. Indeed, variations in G\&T costs explain only $7 \%$ of the variation in ancillary-service costs. ${ }^{*}$

Figure 2 shows the average allocation of aggregate ancillary-service costs among the individual services. On average, losses account for the largest share $(30 \%)$ of ancillary-service costs. Operating reserves account for $34 \%$, split roughly evenly between reliability and supplemental-operating reserves. Load following, energy imbalance, and voltage control each account for about $10 \%$ of total costs, while scheduling and dispatch accounts for $4 \%$.

FERC's (1995) proposed rule suggests that the price for the combination of load following, system protection (the sum of what we call reliability and supplemental-operating reserves), and voltage control be capped at $0.10 \mathrm{k} / \mathrm{kWh}$. Our estimates show that, on average, these services cost a total of $0.23 \notin / \mathrm{kWh}$ (Table 16), more than double FERC's cap. The variation in the cost for these three services $(0.09 \notin / \mathrm{kWh}$ to $0.45 \notin / \mathrm{kWh})$ among the utilities also suggests that these services should be treated individually, allowing the market to set rates where possible.

*Dropping the two outliers (NSP and PacifiCorp) increases the explanatory power of the regression model that explains ancillary-service costs as a function of G\&T costs, from $7 \%$ to $40 \%$. Similarly, the coefficient of variation for ancillary-service costs declines from 0.35 to 0.24 when these two observations are dropped from the sample. 


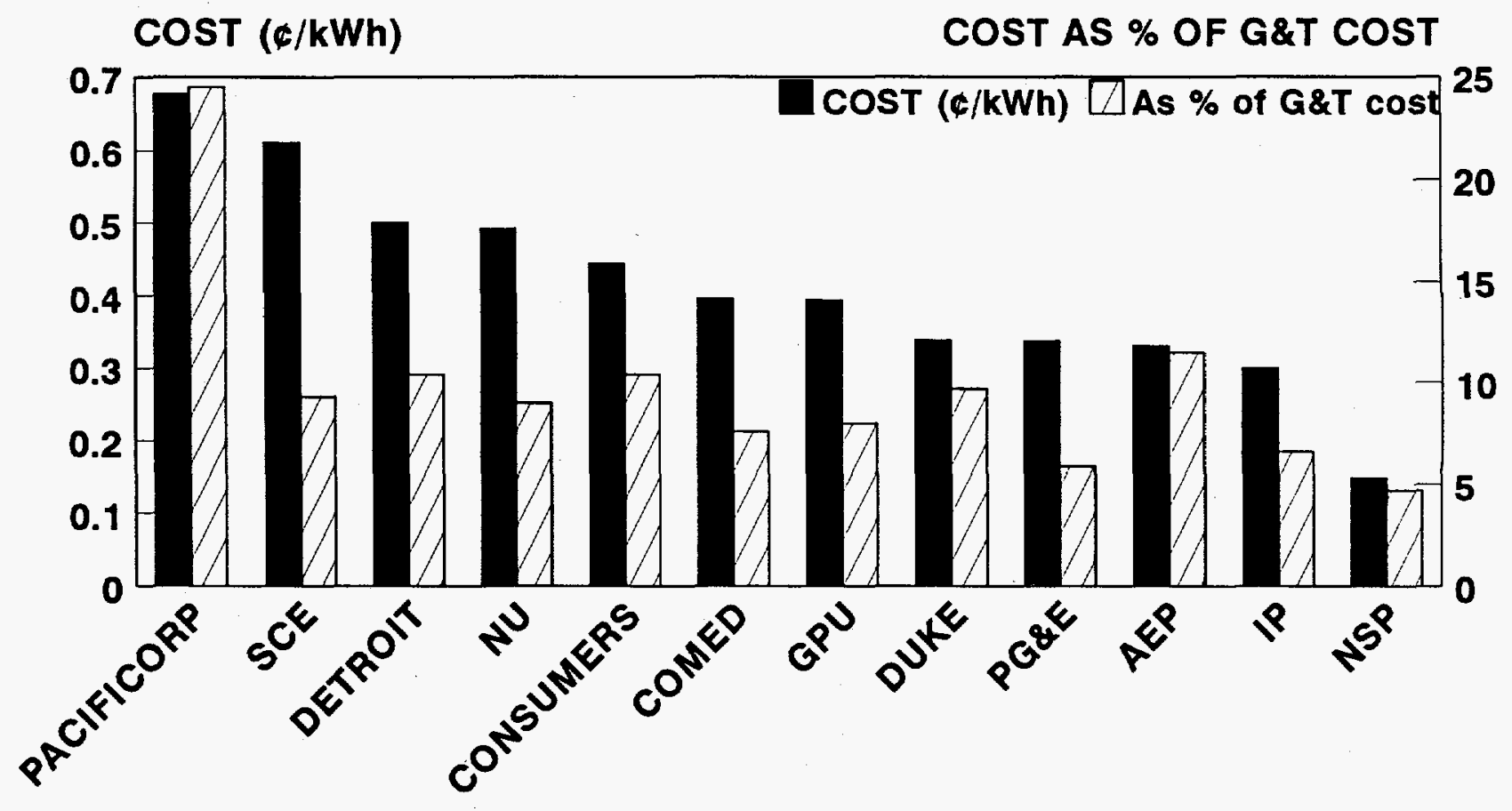

Fig. 1. Ancillary-service costs for 12 U.S. investor-owned utilities.

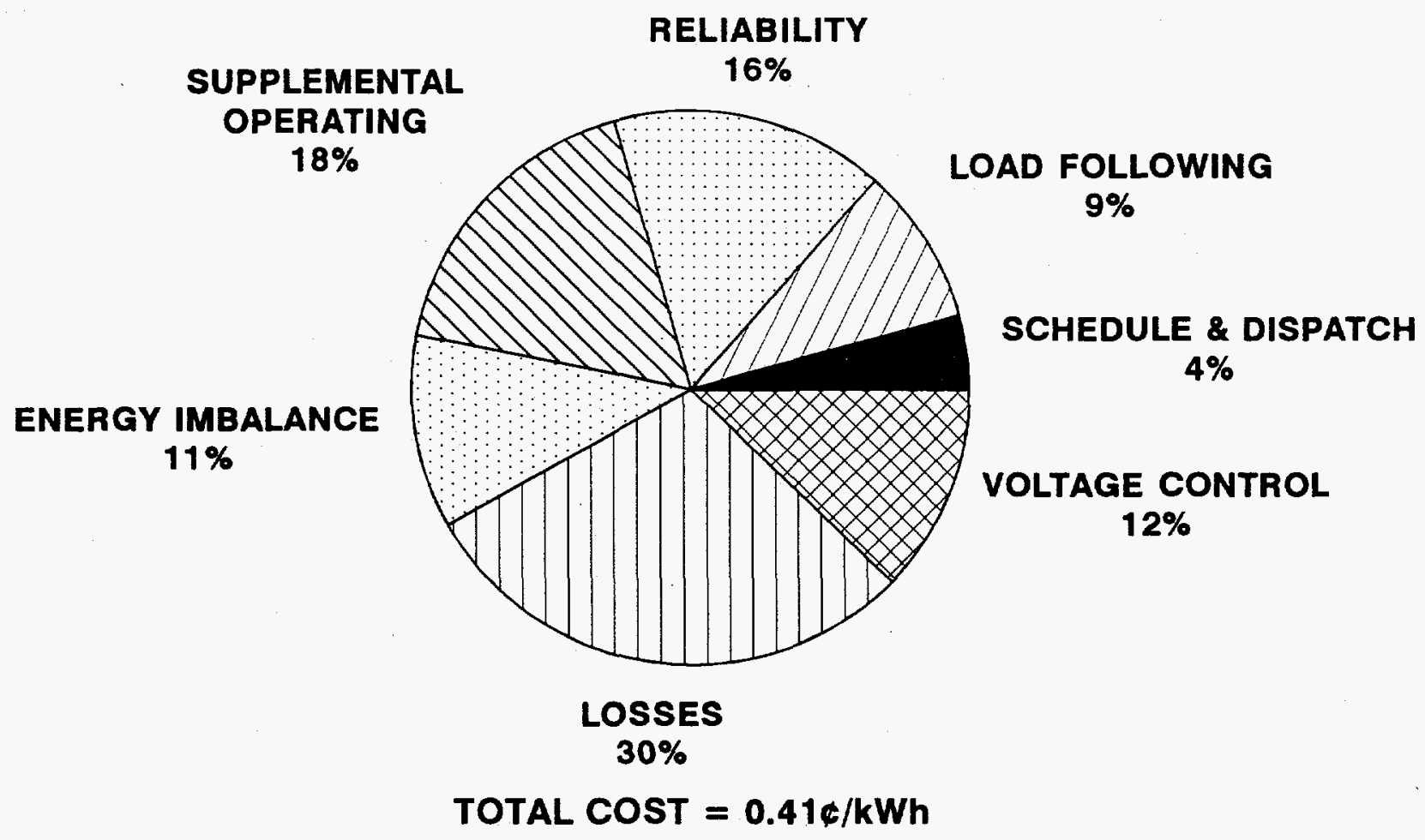

Fig. 2. Average (unweighted mean across 12 utilities) portion of total ancillaryservice cost for each service. 
Figure 3 and Table 16 show the substantial ranges in cost estimates for the individual services. The range is especially large for reliability and supplemental-operating reserves $(0.15$ and $0.20 \mathrm{c} / \mathrm{kWh}$, respectively).

Most utilities provided estimates of reserve requirements and real-power losses. Table 17 presents these values as a percentage of peak generation and total annual energy, respectively. The table also shows the maximum, minimum, and mean values for each factor. The large ranges shown for load following, reliability reserve, and supplemental-operating reserve surely reflect differences in definitions as well as differences in operating requirements.

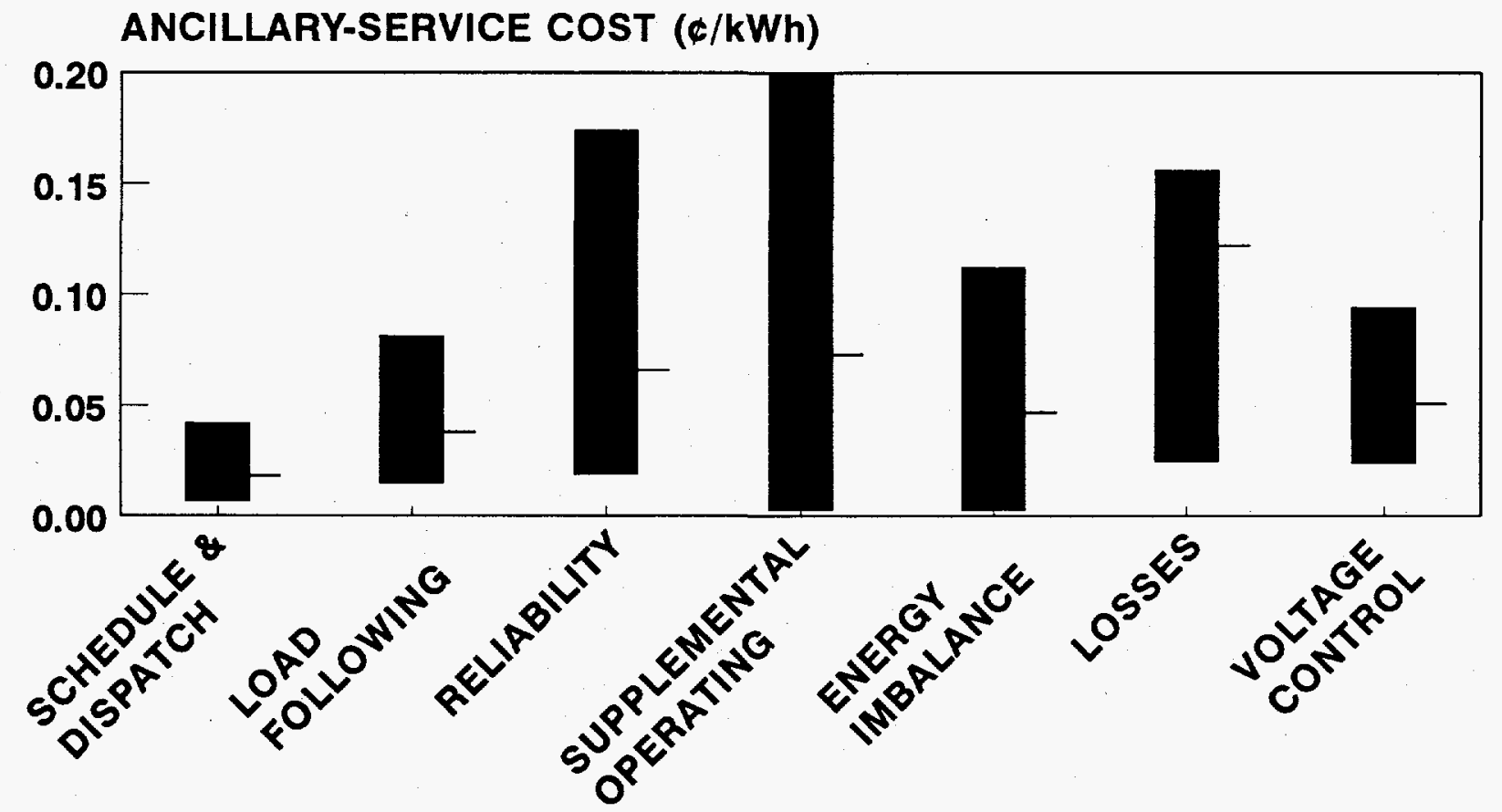

Fig. 3. Range in cost estimates for each ancillary service. The tick marks are the mean values. 
Table 15. Summary of ancillary-service costs (in $\notin / k W h$ ) for 12 U.S. investor-owned utilities ${ }^{2}$

\begin{tabular}{lcccccccccccc}
\hline & AEP & $\begin{array}{c}\text { Com } \\
\text { Ed }\end{array}$ & $\begin{array}{c}\text { Consu- } \\
\text { mers } \\
\text { Power }\end{array}$ & $\begin{array}{c}\text { Detroit } \\
\text { Edison }\end{array}$ & $\begin{array}{c}\text { Duke } \\
\text { Power }\end{array}$ & GPU $^{\mathbf{b}}$ & $\begin{array}{c}\text { Illinois } \\
\text { Power }\end{array}$ & NU & NSP & $\begin{array}{c}\text { Pacifi- } \\
\text { Corp }\end{array}$ & $\begin{array}{c}\text { PG\&E } \\
\text { SCE }\end{array}$ \\
\hline Scheduling \& dispatch & 0.013 & 0.012 & 0.025 & 0.012 & 0.007 & 0.042 & 0.007 & 0.030 & 0.017 & 0.030 & 0.008 & 0.010. \\
Generation reserves & & & & & & & & & & & \\
$\quad$ Load following & 0.046 & 0.016 & 0.051 & 0.049 & 0.018 & 0.015 & 0.037 & 0.050 & 0.019 & 0.081 & 0.034 & 0.033 \\
Reliability & 0.023 & 0.064 & 0.051 & 0.049 & 0.034 & 0.035 & 0.023 & 0.100 & 0.019 & 0.161 & 0.063 & 0.174 \\
$\quad$ Supplemental operating & 0.023 & 0.064 & 0.051 & 0.049 & 0.034 & 0.081 & 0.012 & 0.100 & 0.003 & 0.161 & 0.087 & 0.206 \\
Energy imbalance & 0.042 & 0.053 & 0.105 & 0.112 & 0.036 & 0.003 & 0.050 & 0.038 & 0.015 & 0.043 & 0.019 & 0.046 \\
Real-power losses & 0.155 & 0.136 & 0.137 & 0.156 & 0.115 & 0.145 & 0.142 & 0.123 & 0.025 & 0.150 & 0.076 & 0.107 \\
Voltage control & 0.028 & 0.051 & 0.024 & 0.074 & 0.094 & 0.074 & 0.028 & 0.051 & 0.051 & 0.051 & 0.051 & 0.035 \\
Total ancillary-services cost & 0.331 & 0.396 & 0.444 & 0.501 & 0.339 & 0.394 & 0.300 & 0.492 & 0.149 & 0.677 & 0.338 & 0.611 \\
Total as \% of G\&T cost & 11.5 & 7.6 & 10.4 & 10.4 & 9.7 & 8.0 & 6.6 & 9.0 & 4.7 & 24.5 & 5.9 \\
\hline
\end{tabular}

${ }^{2}$ The numbers in italics are imputed because the utility provided no estimate for that service.

${ }^{\mathrm{b}}$ The totals for GPU exclude the $0.93 \mathrm{c} / \mathrm{kWh}$ reliability-impact charge.

w

Table 16. Range of ancillary-service costs (in $€ / k W h)$ for 12 U.S. investor-owned utilities

\begin{tabular}{lccccc}
\hline & Maximum & Minimum & Average & $\begin{array}{c}\text { As \% of } \\
\text { total AS cost }\end{array}$ & $\begin{array}{c}\text { As \% of total } \\
\text { G\&T cost }\end{array}$ \\
\hline $\begin{array}{l}\text { Scheduling \& dispatch } \\
\text { Generation reserves }\end{array}$ & 0.042 & 0.007 & 0.018 & 4.3 & 0.43 \\
$\quad$ Load following & 0.081 & 0.015 & 0.038 & & \\
Reliability & 0.174 & 0.019 & 0.1 & 0.94 \\
Supplemental operating & 0.206 & 0.003 & 0.073 & 16.0 & 1.54 \\
Energy imbalance & 0.112 & 0.003 & 0.047 & 17.6 & 1.3 \\
Real-power losses & 0.156 & 0.025 & 0.122 & 29.5 & 1.10 \\
Voltage control & 0.094 & 0.024 & 0.051 & 12.3 & 2.93 \\
Total cost or percent & 0.677 & 0.149 & 0.414 & 100.0 & 1.22 \\
\hline
\end{tabular}


Table 17. Generating-reserve requirements and real-loss factors (\%) for 12 U.S. investor-owned utilities

\begin{tabular}{|c|c|c|c|c|c|}
\hline & \multirow{2}{*}{$\begin{array}{c}\text { Load } \\
\text { following }\end{array}$} & \multirow[b]{2}{*}{ Reliability } & \multirow{2}{*}{$\begin{array}{c}\text { Supple- } \\
\text { mental } \\
\text { operating }\end{array}$} & \multicolumn{2}{|c|}{ Real-power losses } \\
\hline & & & & Demand & Energy \\
\hline AEP & 3.0 & 1.5 & 1.5 & 3.6 & 3.6 \\
\hline ComEd & 0.8 & - 2.1 & - & 2.7 & 2.3 \\
\hline Consumers & - 3.0 & -----.---.- & 3.0 & --.-- 3.0 & -.-- \\
\hline Detroit Edison & ------- 3.0 & - & 3.0 & 3.0 & - \\
\hline Duke & 2.3 & 3.5 & -- & 3.0 & 3.0 \\
\hline GPU & 1.2 & 1.5 & 3.5 & 3.0 & 3.0 \\
\hline Illinois Power & -- & -- & -- & 2.7 & 2.1 \\
\hline NU & -- & 5.5 & 5.5 & 2.7 & 2.7 \\
\hline NSP & 1.0 & 2.1 & 2.1 & 2.4 & 2.4 \\
\hline PacifiCorp & 3.5 & 7.0 & ------.. & 4.6 & 4.6 \\
\hline PG\&E & 2.8 & 7.0 & 8.0 & 3.0 & ------- \\
\hline SCE & 7.7 & 7.0 & 9.0 & 2.8 & 2.7 \\
\hline Maximum & 7.7 & 7.0 & 9.0 & 4.6 & 4.6 \\
\hline Minimum & 0.8 & 1.5 & 2.1 & 2.4 & 2.1 \\
\hline Mean & 2.8 & 4.0 & 4.5 & 3.1 & 2.9 \\
\hline
\end{tabular}





\section{CONCLUSIONS}

The data and estimates we obtained from 12 U.S. utilities show that ancillary-service costs are a nontrivial share of total generation plus transmission costs. For the utilities in our sample, the cost of ancillary services ranges from 0.15 to $0.68 \notin / \mathrm{kWh}$, and represents 5 to $25 \%$ of generation-plus-transmission costs. Ancillary-service costs can rise dramatically above these values on constrained systems, as shown by the GPU results. On a national aggregate basis, ancillary services cost $\$ 12$ billion annually.

These results also show substantial differences across utilities in their estimates of the costs of individual services. The most extreme examples are reliability and supplementaloperating reserves, for which the estimates vary by as much as $0.2 \% / \mathrm{kWh}$ across utilities. These ranges suggest that additional work is needed to define each service, to identify just how much of each service is required, and to establish the fixed and variable costs for each service. Such efforts should focus on the generation-related services (reserves and loss replacement) because they are the most expensive services. Fortunately, these services are the ones most likely to be available competitively, which reduces the regulatory burden to develop and review cost estimates for these services.

Scheduling and dispatch and voltage control, on the other hand, are relatively inexpensive and may not merit as much additional research. These services are likely to be provided by the local control area and therefore may remain regulated.

We plan to continue our work on ancillary services. We will seek to obtain data, assumptions, and analyses on these costs from other utilities, especially those in the regional reliability councils not represented by the 12 utilities in the current sample. We also plan to develop methods to estimate the amounts of each service needed and the associated costs of each service. These methods should be especially helpful as the provision of some of these services becomes more competitive than they are today.

\section{ACKNOWLEDGMENTS}

We thank Bernard Pasternack (American Electric Power), Steven Naumann (Commonwealth Edison), Antonio Sammut and Lawrence Worobec (Detroit Edison), Steven Young and Jennifer Burnett (Duke Power), Bradley Breidinger and Javier Funes (General Public Utilities), Kevin Shipp (Illinois Power), Carl Psoter (Northeast Utilities), Terry Grove (Northern States Power), Jack Stamper (PacifiCorp), Roger Yang and Stephen Metague (Pacific 
Northeast Utilities Service Company 1995, Transmission Tariff Filing, before the Federal Energy Regulatory Commission, Docket No. ER95-1686-000, Hartford, CT, September.

Northern States Power Company 1995, Electric Tariff, submitted to the Federal Energy Regulatory Commission, Docket Nos. ER94-1090-000 and ER94-1113-000, Minneapolis, MN, March 13.

Pacific Gas and Electric Company 1994, Initial Rate Filing for the Control Area and Transmission Service Agreement Between Pacific Gas and Electric Company and Destec Power Services, Inc., Docket No. ER95-262-000, before the Federal Energy Regulatory Commission, San Francisco, CA, December 5.

PacifiCorp 1995, Transmission Tariff Filings, submitted to the Federal Energy Regulatory Commission, Docket No. ER95-124-000, Portland, OR, June.

D. Parker 1995, personal communication, Systems Operation Department, Southern California Edison, Rosemead, CA, July.

B. Pasternack 1995, personal communication, Transmission Planning Department, American Electric Power Service Corp., Columbus, OH, October.

C. Psoter 1995, personal communication, Regulatory Transition Department, Northeast Utilities Service Company, Hartford, CT, November.

A. Sammut 1995, personal communication, Regulatory Affairs Department, Detroit Edison, Detroit, MI, August.

K. Shipp 1995, personal communication, Regulatory Affairs Department, Illinois Power Company, Decatur, IL, August.

J. Stamper 1995, personal communication, PacifiCorp, Portland, OR.

U.S. Federal Energy Regulatory Commission 1992, "FERC Form No. 1: Annual Report of Major Electric Utilities, Licensees and Others," Washington, DC.

U.S. Federal Energy Regulatory Commission 1995, Promoting Wholesale Competition Through Open Access Non-discriminatory Transmission Services by Public Utilities, Recovery of Stranded Costs by Public Utilities and Transmitting Utilities, Docket Nos. RM95-8-000 and RM94-7-001, Washington, DC, March 29.

R. Yang 1995, personal communication, Grid Customer Services Department, Pacific Gas \& Electric Company, San Francisco, CA, October. 


\section{INTERNAL DISTRIBUTION}

1. D. Bauer

2. L. Baxter

3. V. D. Baxter

4. L. Berry

5. D. S. Bjornstad

6. R. Braid

7. M. A. Brown

8. J. Christian

9. G. Courville

10. T. R. Curlee

11. P. D. Fairchild

12. S. Hadley

13. L. J. Hill

14. E. Hillsman

15. E. Hirst

16. P. J. Hughes

17. B. Kirby

18. R. Lee

19. P. Leiby
20. J. M. MacDonald

21. V. C. Mei

22. D. E. Reichle

23. D. T. Rizy

24. A. C. Schaffhauser

25. M. Schweitzer

26. R. B. Shelton

27. J. Tomlinson

28. B. E. Tonn

29. J. Van Dyke

30. J. Vancoevering

31. J. M. Veigel (ORAU)

32. T. J. Wilbanks

33. ORNL Patent Office

34. Central Research office

35. Document Reference Section

36. Laboratory Records (RC)

37-39. Laboratory Records Dept.

\section{EXTERNAL DISTRIBUTION}

40. Dr. Thomas E. Drabek, Professor, Department of Sociology, University of Denver, Denver, CO 80208-0209

41. Dr. Stephen G. Hildebrand, Director, Environmental Sciences Division, Oak Ridge National Laboratory, Post Office Box 2008, Oak Ridge, TN 37831-6037

42. Mr. George F. Sowers, P. E., Senior Vice President, Law Companies Group, Inc., 114 Townpark Drive, Suite 250, Kennesaw, GA 30144-5599

43. Dr. C. Michael Walton, Ernest H. Cockrell Centennial Chair in Engineering and Chairman, Department of Civil Engineering, University of Texas at Austin, Austin, TX 78712-1076

44.-46. OSTI, U. S. Department of Energy, P. O. Box 62, Oak Ridge, TN 37831

47. Office of Assistant Manager for Energy Research and Development, DOE/ORO, P. O. Box 2001, Oak Ridge, TN 37831-8600

48.-700. External Electric Industry Policy Studies group distribution mailing list and extra copies to E.M. Schorn, $4500 \mathrm{~N}, \mathrm{H}-19 \mathrm{~A}$ 

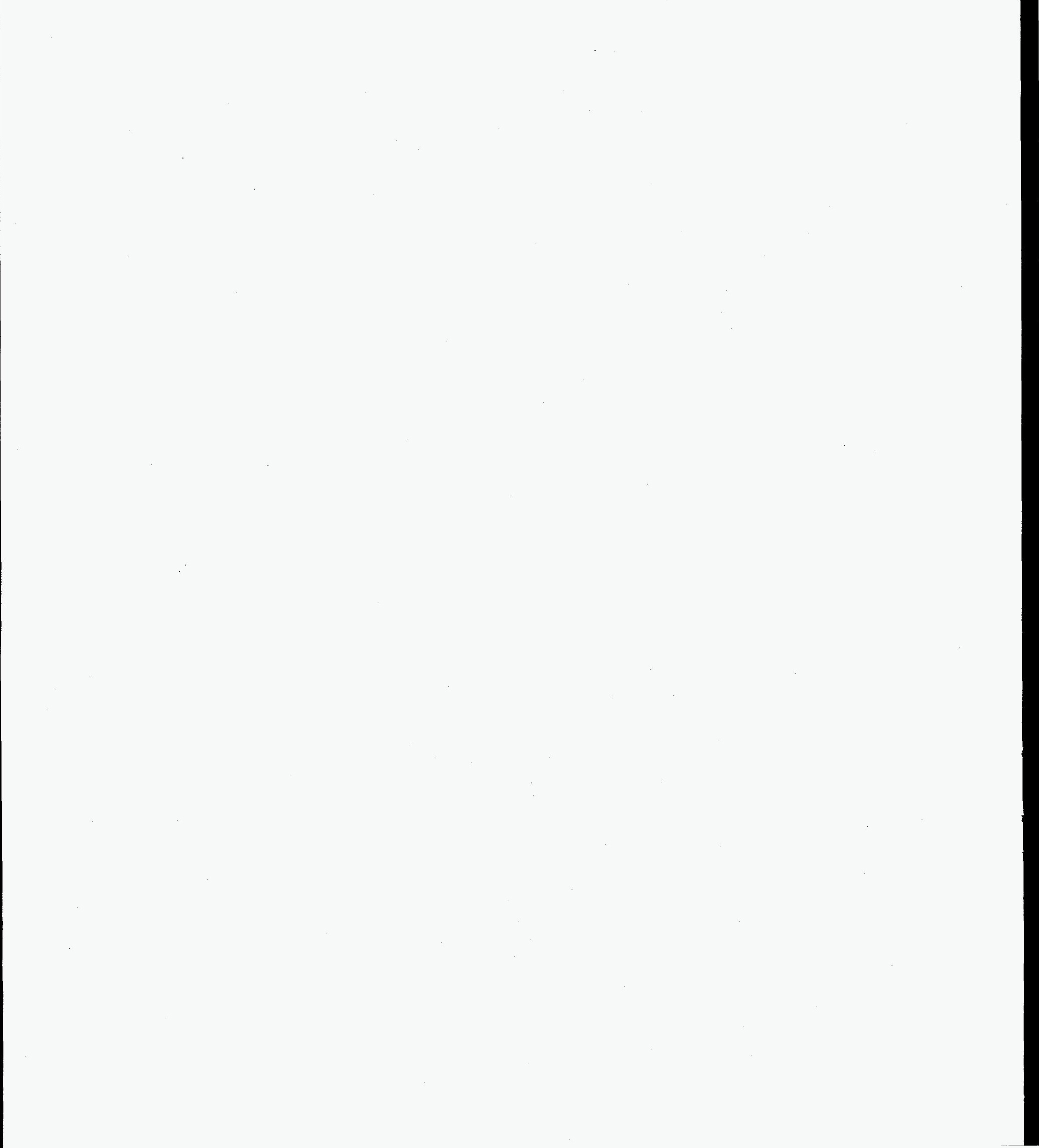